\title{
Istočno bojište 1915. u najnovijoj britanskoj i hrvatskoj historiografiji
}

\author{
FILIP KATANIĆ \\ Zagreb, Hrvatska \\ katani.filip@gmail.com
}

\begin{abstract}
U radu se razmatraju radovi pojedinih britanskih i hrvatskih autora o Istočnom bojištu 1915. u Prvom svjetskom ratu objavljeni od 2014. do 2017. godine. Prvenstveni je cilj komparativnom analizom postaviti okvir strukturnom i specijalističkom proučavanju Prvoga svjetskog rata u historiografiji. Propituju se do sada ustaljeni historiografski stavovi o stanju na Istočnom bojištu 1915. i neki mitovi o snazi i borbenoj spremnosti austrougarske vojske. Postavljaju se tri pitanja: 1 . Koliko je opravdana teza o inferiornosti austrougarske vojske u odnosu na njemačku i rusku vojsku? 2. Je li Prvi svjetski rat mogao završiti već 1915. kao posljedica događaja na Istočnom bojištu? 3. Može li se procijeniti broj poginulih, ranjenih, zarobljenih i nestalih hrvatskih vojnika i časnika u borbama na Istočnom bojištu 1915. godine?
\end{abstract}

Ključne riječi: Istočno bojište; Prvi svjetski rat; britanska historiografija; hrvatska historiografija; austrougarska vojska; njemačka vojska; ruska vojska

\section{Radovi pojedinih britanskih i hrvatskih autora o Istočnom bojištu 1915. u Prvom svjetskom ratu}

Kako se približavala stogodišnjica izbijanja Prvoga svjetskog rata 2014., tako se broj specijaliziranih radova koji se bave događajima na Istočnom bojištu u britanskoj i hrvatskoj historiografiji povećao. O Istočnom bojištu 1915. u Prvom svjetskom ratu u posljednje tri godine napisano je nekoliko znanstveno-publicističkih radova objavljenih na engleskom i hrvatskom jeziku. Te radove možemo podijeliti u dvije skupine. U prvoj se nalaze povjesničari koji su dali sintetske preglede tijeka ratnih operacija, vojnoga stanja i analize snage i borbene spremnosti vojski zaraćenih strana na Istočnom bojištu 1915. godine. To su britanski povjesničari Richard Bassett i Prit Buttar te hrvatski povjesničari Zvonimir Freivogel i pukovnik Nikola Tominac. U drugoj skupini radova nalaze se autori koji su također dali sintetske preglede, ali su se u njima bavili 
različitim aspektima rata (političkim, vojnim, ekonomskim i kulturnim). To su britanski povjesničari Dominic Lieven, David Stevenson i Alexander Watson. Od hrvatskih autora zastupljeni su Vijoleta Herman Kaurić i Jevgenij Paščenko $^{1}$, a Igor Despot, Filip Hameršak, Vijoleta Herman Kaurić, Helena Miljević Pavić i Krešimir Škuljević sastavili su jedini sintetski pregled Prvoga svjetskog rata u domaćoj historiografiji, u obliku cjelovitoga udžbenika i kompendija o Prvom svjetskom ratu naslova Prvi svjetski rat. Čitanka-priručnik za učitelje i profesore povijesti u osnovnoj školi i gimnaziji. ${ }^{2}$ Naravno, postoje i drugi radovi u hrvatskoj historiografiji koji se bave različitim temama i aspektima Prvoga svjetskog rata, ali se nisu posebno analizirali u ovom radu jer se ne bave Istočnim bojištem. ${ }^{3}$

Britanski povjesničar Richard Bassett napisao je knjigu For God and Kaiser. Premda se knjiga bavi poviješću carske habsburške vojske od njezina osnutka 1619. do raspada i kraja Monarhije 1918., znatan je dio posvećen austrougarskoj vojsci u Prvom svjetskom ratu (str. 435 - 540). Dio koji se odnosi na ratne operacije austrougarske vojske na Istočnom bojištu nalazi se u 23. poglavlju “1915. - 1916. Bajunete u Dolomitima” (str. 480 - 497). Kao primarni izvor za ovu knjigu koristila se arhivska građa u Beču (Kriegsarchiv, Haus-, Hof- und Staatsarchiv, Službene publikacije austrijske vojske i Sjećanja pojedinih dužnosnika $^{5}$ ) i Budimpešti (Pannonhalma /Sv. Martinbreg/). Kao sekundarni izvor koristilo se mnogo selektirane bibliografije, čak 468 bibliografskih jedinica. Osim toga, autor se koristio i metodologijom usmene povijesti. Tehnikom intervjua $\mathrm{u}$ razgovorima $\mathrm{s}$ pojedinim potomcima protagonista tih događaja (vojnih operacija na Istočnom bojištu i političkih događaja u Monarhiji iste godine) prikupio je brojne podatke koje je iznio u knjizi na zanimljiv i originalan način.

Prit Buttar stručnjak je za vojnu povijest Istočnoga bojišta ${ }^{6}$. Za svaku ratnu godinu Prvoga svjetskog rata napisao je po jednu knjigu: Collision of Empires, koja se bavi Istočnim bojištem 1914., Germany Ascendant, koja se analizira u

1 Jevgenij Paščenko po nacionalnosti je Ukrajinac. Profesor je ukrajinskoga jezika i književnosti na Filozofskom fakultetu Sveučilišta u Zagrebu. Kako je do sada napisao 12 knjiga i nekoliko drugih radova o ukrajinsko-hrvatskim vezama tijekom povijesti na hrvatskom jeziku, ovdje je uvršten u skupinu hrvatskih povjesničara.

2 DESPOT et al., Prvi svjetski rat.

3 To su radovi hrvatskih povjesničara Ivana Bulića, Dinka Čuture, Mislava Gabelice, Zdravke Jelaska Marijan, Hrvoja Čape, Filipa Hameršaka, Vijolete Herman Kaurić, Ivana Peklića, Milana Pojića, Drage Roksandića i Marka Vukičevića. I izdanje hrvatskoga časopisa Review of Croatian History 10 (2014), br. 1 sadržava tematski blok posvećen raznim temama iz Prvoga svjetskog rata.

4 Bassett je kombinirao prikaz ratnih operacija s Jugozapadnoga (Talijanskoga) i Istočnoga bojišta.

5 Sam autor svrstava ih u primarne izvore.

6 Osim spomenute četiri knjige o Istočnom bojištu u Prvom svjetskom ratu, autor je napisao i dvije knjige o Istočnom bojištu u Drugom svjetskom ratu: Battleground Prussia. The Assault on Germany's Eastern Front 1944-45 (London: Osprey Publishing, 2010) i Between Giants. Battle for the Baltic in World War II (London: Osprey Publishing, 2013). 
ovom radu, a bavi se Istočnim bojištem 1915., i Russia’s Last Gasp, koja obrađuje Istočno bojište 1916. godine. Njegova posljednja knjiga, The Splintered Empires, koja se bavi događajima na Istočnom bojištu 1917., izašla je u rujnu 2017. godine. Ovdje se analizira knjiga Germany Ascendant. The Eastern Front 1915. U njoj autor detaljno izlaže tijek svih borbenih operacija koje su se dogodile na Istočnom bojištu tijekom 1915., pa je knjiga strukturirana tako da svaku pojedinu glavnu vojnu operaciju svrstava u posebno poglavlje: 2. poglavlje "Prva karpatska kampanja" (str. 57 - 77), 3. poglavlje "Zima u Mazuriji” (str. 78 - 117), 4. poglavlje "Proljeće" (str. 118 - 156), 5. poglavlje "Mackensenov proboj" (str. 157 - 200), 6. poglavlje "Iskorištavanje" (str. 201 - 235), 7. poglavlje "Lavov" ("Lemberg", str. 236 - 264), 9. poglavlje "Veliko povlačenje" (str. 293 - 328) i naposljetku 10. poglavlje "Volinj. Kraj povodca" (str. 329 - 360).

Osim što se Buttar specijalistički detaljno bavi vojnom poviješću, tematskim pristupom analizirao je i stanje u svim zaraćenim vojskama (njemačkoj, austrougarskoj i ruskoj) u različitim fazama borbenih djelovanja tijekom 1915., uspoređujući njihove snage. Kao izvore korištene u ovoj knjizi autor je od primarnih naveo arhive u Bonnu (Auswärtiges Amt), Freiburgu (Bundesarchiv-Militärarchiv), Moskvi (Voyenno-istoričeskij arhiv), Münchenu (Bayerisches Hauptstaatsarchiv), Stanfordu (Hoover Institution Archives) i Beču (Kriegsarchiv/Staatsarchiv). Od sekundarnih izvora koristila su se četiri časopisa: Zeitschrift für Unternehmensgeschichte (Beck, München), Strategy and Tactics (Bakersfield), Science in Context (Cambridge) i Voennoistoričeski sbornik (Sofija) te 133 bibliografske jedinice.

Zvonimir Freivogel iznio je u knjizi Austrougarska vojska u prvom svjetskom ratu detaljan uvid u brojčano stanje, opremljenost, tehničke karakteristike naoružanja i organizaciju opskrbe i prijevoza austrougarske vojske u Prvom svjetskom ratu. To je ujedno i prva cjelovita knjiga napisana na hrvatskom jeziku o austrougarskoj vojsci u Prvom svjetskom ratu. Autor se također odlučio za tematski pristup, koji u pojedinim poglavljima kombinira s kronološkim izlaganjem. Dio svakoga tematskog poglavlja posvećen je i jednom razdoblju od ustroja zajedničke Carske i kraljevske vojske, pa i prije, čak od 1866., do izbijanja rata 1914., a poslije se nastavlja s opisom razvoja i napretka pojedinih rodova vojske i naoružanja tijekom rata. Posebna je pozornost posvećena austrougarskoj mornarici i zrakoplovstvu (kao najnovijem rodu oružane sile) u Prvom svjetskom ratu.

Najveći prigovor ovoj knjizi koji bi se mogao istaknuti jest da autor u tekstnom dijelu nije u bilješkama naznačio kojim se izvornim arhivskim gradivom koristio za pojedini podatak ili eventualno literaturom kada bi citirao pojedini navod. Za vizualni je pak dio koristio brojne fotografije iz privatnih i državnih arhiva, uz koje postoji oznaka gdje se nalaze. Zapravo se može zaključiti da za većinu navoda u tekstu i nije koristio arhivsko gradivo nego isključivo literaturu, jer na kraju knjige autor zahvaljuje ustanovama i arhivima na ustupanju fotografija, ne navodeći pritom koje je fondove koristio u tekstnom dijelu. Stoga samo valja istaknuti da se od važnijih arhiva koristilo gradivo iz 
Vojnoga povijesnog muzeja u Beču (Heeresgeschichtliches Museum) i gradivo u Knjižnici u Stuttgartu (Bibliothek für Zeitgeschichte). Od sekundarnih izvora koristilo se 15 bibliografskih jedinica, od kojih bi najvažnije bilo istaknuti knjige Christophera Clarka The Sleepwalkers, Edmunda Glaisea von Horstenaua Österreich-Ungarns letzter Krieg 1914-1918 i Manfrieda Rauchensteinera Der Tod des Doppeladlers.

Posljednji u ovoj skupini rad je vojnoga povjesničara pukovnika Nikole Tominca "Ličani u 'Velikom ratu'. Zimska bitka za Karpate, siječanj - travanj 1915”. Ovaj specijalizirani znanstveni rad detaljno analizira rečenu bitku, a pojedinačno se bavi i ratnim putom jedne hrvatske vojne postrojbe, 79. pješačke pukovnije Zajedničke vojske iz Otočca (K.u.K. Otočaner Infanterieregiment Graf Jellačić Nr. 79. - IR 79), poznatije kao "Jelačićevci”, koja je ratovala u sastavu austrougarske 7. pješačke divizije (Gruppe Szurmay) kao dijela 3. armije pod zapovjedništvom generala Svetozara Borojevića. U sastavu te armije vrlo važnu zapovjednu funkciju ima još jedan hrvatski general iz Like: Pavao pl. Puhallo od Brloga. ${ }^{7}$ Tematski i metodološki, rad je najsličniji Buttarovoj knjizi, a potpuno različitoga metodološkog pristupa od Freivogelove knjige. Odlično se uklapa u ovu cjelinu jer popunjava spomenute historiografske praznine Freivogelove knjige, koja se ovom temom uopće ne bavi, a nudi dosta podataka za usporedbu s Buttarovom knjigom.

Tominac je posebno analizirao borbena djelovanja u teškim zimskim uvjetima, determiniranim zemljopisnim značajkama neprohodnoga terena, uz prikaz tehničko-operativnih elemenata borbenih djelovanja. Koristio je nekoliko važnih izvora. Od primarnih, koristilo se gradivo u Hrvatskom državnom arhivu u Zagrebu, Matične knjige umrlih vojnih osoba 79. pješačke pukovnije 1914. - 1919., te gradivo u arhivima u Austriji: Österreichisches Staatsarchiv (ÖeStA) - Kriegsarchiv (KA), Namentliche Verlustliste IR 79, Österreich-Ungarns letzter Krieg 1914-1918, vol. 2, Das Kriegsjahr, 1915, Vom Ausklang der Schlacht bei Limanowa-Lapanow bis zur Einnahme von Brest-Litowsk, Bundesministerium für Heereswesen und vom Kriegsarchiv (1931.), ÖeStA-KA, Neue Feld Akten za IR 79 i 7. ID. Kao sekundarne izvore autor navodi 11 bibliografskih jedinica. Važno bi bilo istaknuti da su tri autora iz ove skupine radova, Bassett, Buttar i Tominac, koristila arhivsko gradivo iz bečkoga arhiva (među ostalim), od sekundarnih izvora samo djelomično istu memoarsku literaturu, a u specijaliziranom dijelu uglavnom su koristili različite radove, uz iznimku knjiga kao što su primjerice The Eastern Front 1914-1917 Davida Stonea i Blood on the Snow: The Carpathian Winter War of 1915 G. A. Tunstalla, koje obilno koriste sva tri autora.

U drugoj skupini radova Dominic Lieven u svojoj knjizi Towards the Flame bavi se poviješću Rusije od 1904. do 1920. godine. Proučava rusku ulogu u događajima koji su prethodili izbijanju Prvoga svjetskog rata, a poslije tumači kako je tekao rat iz ruske perspektive do izbijanja dviju revolucija 1917. godi-

\footnotetext{
TOMINAC, "Ličani u 'Velikom ratu", 489.
} 
ne. Naposljetku analizira posljedice ruske revolucije za međunarodne odnose. Lieven je za ovu knjigu obilno koristio arhivsko gradivo u Beču (ÖsterreichUngarns Aussenpolitik von der bosnischen Krise bis zum Kriegsausbruch 1914), Berlinu (Die grosse Politik der europäischen Kabinette, 1871-1914), Londonu (Nacionalni arhiv, Kew, zajedno s britanskim dokumentima o podrijetlu rata od 1898. do 1914.), Moskvi (Arhiv vanjske politike Ruskoga Carstva, Državni arhiv Ruske Federacije, Krasnij arhiv, Ruski državni vojno-povijesni arhiv), New Yorku (Columbia University Bakhmeteff Archive), Sankt Peterburgu (Arhiv Akademije znanosti, Ruski državni pomorski arhiv i Ruski državni povijesni arhiv) i Parizu (Francuski vojni arhiv). Koristila se 341 bibliografska jedinica, od čega je bitno izdvojiti knjigu Normana Stonea The Eastern Front 1914-1917, koju su koristili i drugi autori iz ovoga rada.

David Stevenson autor je jedine cjelovite knjige o Prvom svjetskom ratu prevedene s engleskoga na hrvatski jezik: 1914. - 1918. Povijest Prvog svjetskog rata. ${ }^{8} \mathrm{U}$ njoj se bavi svim aspektima Prvoga svjetskog rata te izvodi posebne zaključke u pogledu pojedinoga tematskog bloka. Istočnom bojištu 1915. posvećuje jedan, dovoljno važan, dio knjige, iako događajima sa Zapadnoga bojišta posvećuje veću pozornost jer drži da je ono bilo ključno za cjelokupni ratni ishod. Kronološkim pristupom pojedine su tematske cjeline oblikovane u poglavlja prema fazama u kojima se rat vodio. Istočno bojište 1915. obrađuje se unutar cjeline "Eskalacija" (str. 171 - 405), koja se bavi događajima od proljeća 1915. do proljeća 1917. godine. Za razliku od većine autora (osim Freivogela), Stevenson nije naznačio izvore koje je koristio onako kako su to izložili drugi autori. Iz popisa kratica jedino se može razaznati da se od primarnih izvora za ovu knjigu koristilo arhivsko gradivo u Austriji, Australiji, Francuskoj, Njemačkoj, Rusiji i Velikoj Britaniji (uglavnom vojni fondovi), a na popisu literature nalaze se 744 bibliografske jedinice.

S druge strane, upravo u knjizi Ring of Steel britanskoga autora Alexandera Watsona nalazi se obilje podataka koji su u Stevensonovoj knjizi izostali. Knjiga se bavi Njemačkom i Austro-Ugarskom u Prvom svjetskom ratu, a izazvala je veliko zanimanje javnosti i povjesničara te $2014 .{ }^{9}$ dobila nagradu "Guggenheim-Lehrman" za knjigu godine o vojnoj povijesti i povijesnu knjigu godine britanskih novina The Sunday Times. Radi se o (nimalo pristrano, može se konstatirati!) doista vrijednom djelu koje sadržava obilje podataka iz različitih područja: političke, vojne, društvene i ekonomske povijesti. Znatan prostor posvećen je i ratnim strahotama i patnjama civilnoga stanovništva tijekom borbi na Istočnom bojištu cijelo vrijeme trajanja sukoba. Watson je koristio najviše izvora od svih autora čiji su radovi ovdje prezentirani: brojne arhive u Austriji, Izraelu, Njemačkoj, Poljskoj i Velikoj Britaniji, određeni broj časopisa

8 STEVENSON, 1914. - 1918., 304.

9 U ovom je radu korišteno izdanje izdavačke kuće Penguin Books iz Londona iz 2015. godine. Knjigu je prvi put izdala izdavačka kuća Allen Lane iz Londona 2014., kada je knjiga dobila spomenutu nagradu. 
i tiskovina (13), 800 bibliografskih jedinica i čak 14 neobjavljenih doktorskih disertacija.

Jevgenij Paščenko napisao je zanimljivu knjigu Hrvatski grobovi 1914. 1918. Karpati, Galicija, Bukovina, koja se sastoji od nekoliko tematskih cjelina, a za potrebe ovoga rada najbitnije je istaknuti dvije. Prva se bavi rekonstrukcijom ratnih operacija 1915. na Istočnom bojištu prikazom djelovanja i kretanja hrvatskih postrojbi. Pritom autor nije navodio samo pojedine ratne operacije i borbena djelovanja nego i svjedočanstva i zapise lokalnoga ukrajinskog stanovništva u sklopu cjelovite rekonstrukcije svakodnevnoga života u ratnim uvjetima Istočnoga bojišta. Druga je cjelina posvećena obilježavanju brojnih poznatih grobnica i grobova poginulih hrvatskih vojnika na bojištima u Galiciji, Bukovini, Karpatima i ostalim područjima današnje zapadne Ukrajine kao i navođenju neobilježenih mjesta stradanja radi ustanovljivanja identiteta poginulih za koje postoji određeni stupanj vjerojatnosti da su bili hrvatski vojnici.

Dio knjige koji se odnosi na borbena djelovanja hrvatskih postrojbi na Istočnom bojištu 1915. preuzet je iz rada pukovnika Tominca jer su se koristili isti izvori. No samo za slikovni dio Paščenko se koristio arhivskim gradivom iz Hrvatskoga državnog arhiva u Zagrebu, Državnoga arhiva u Beču i podacima s raznih arhivskih internetskih stranica u Ukrajini, Mađarskoj i Poljskoj. Kao sekundarne izvore koristio je nekoliko važnih radova hrvatskih, mađarskih i ukrajinskih povjesničara, privatne informacije potomaka stradalih hrvatskih vojnika i službene zapise administrativnih ukrajinskih tijela u pogledu lokacija grobnica i grobova iz Prvoga svjetskog rata u današnjoj Ukrajini.

Kako je priroda ratnoga sukoba kompleksna, a time i pristup temi pojedinih autora sveobuhvatan, spomenuti su autori u svojim radovima kombinirali navedene elemente po kojima su njihovi radovi podijeljeni u skupine. Primjerice, Buttar i Watson na mnogim mjestima navode doživljaje rata pojedinih časnika i običnih vojnika, zgode iz svakodnevnoga ratnog života i strahote civila, premda se u svojim radovima ne bave isključivo autobiografijom sudionika ratnih zbivanja, nego kombiniraju autobiografske elemente s narativnom tehnikom da bi dokazali pojedine teze i kontekstuirali određene događaje.

Jednako bi se moglo reći i za Paščenka, koji se nije specijalizirano bavio vojnim operacijama na Istočnom bojištu 1915., nego samo navodi sva borbena djelovanja hrvatskih vojnika u sklopu austrougarske vojske tijekom cijeloga razdoblja od kolovoza 1914. do ljeta 1917. godine. Ipak, znatan dio knjige posvetio je i tom aspektu sukoba bez kojega pozadina glavne tematske cjeline, sudbine hrvatskih vojnika na Istočnom bojištu, ne bi bila razumljiva. Paščenko je jednostavno morao navesti lokalitete i kronologiju pojedinih bitaka u kojima su hrvatski vojnici sudjelovali da bi točno naznačio mjesto njihove pogibije, zarobljavanja ili barem približno mjesto nestanka i pravilno ih povezao s lokalitetima hrvatskih grobnica i grobova u Karpatima, Galiciji i Bukovini u pravilan vremensko-činjenični kontekst. 
Istočno bojište 1915. godine

Na početku 1915. Istočno bojište protezalo se od Baltičkoga mora na sjeveru preko sjevernoga, istočnoga i jugoistočnoga dijela Istočne Pruske ${ }^{10}$, preko središnje Poljske južno do teritorija Austro-Ugarske zapadne i srednje Galici$\mathrm{je}^{11}$ te naposljetku do Černjivaca ${ }^{12} \mathrm{u}$ Bukovini ${ }^{13}$ (današnja Ukrajina) i predratne austrougarsko-ruske granice. Njemačka i Austro-Ugarska s jedne te Rusija s druge strane bile su zaraćene strane u sukobu. Sveukupno je na početku 1915. na toj bojišnici bilo sučelice 17 armija, od čega tri njemačke i pet austrougarskih s jedne i devet ruskih s druge strane. Austrougarski grad-tvrđava Przemyśl ${ }^{14} \mathrm{u}$ Galiciji (današnja južna Poljska) nalazio se u okruženju i pod opsadom ruske 11. armije 70 kilometara sjeverno iza crte bojišnice na sektoru gdje su sučelice stajale austrougarska 3. protiv ruske 8 . armije.

Opće odrednice Istočnoga bojišta 1915. donosi Stevenson u knjizi 1914. 1918.: "Sa svojih 1700 kilometara, Istočna fronta, bila je početkom 1915. dvostruko dulja od Zapadne, premda ju je rusko povlačenje skratilo na $1000 \mathrm{~km}$, da bi je rumunjska kampanja opet produljila za dodatnih $400 \mathrm{~km}$. Armije koje su se ondje borile bile su znatno manje od onih na zapadu, pa je i broj vojnika u odnosu na prostor bio manji. Zimi 1915/16. zapadni saveznici držali su 2134 vojnika po kilometru fronte, a Rusija samo 1200 . Na sektoru iste veličine Njemačka je na istoku držala jednu i pol diviziju, a u Francuskoj ili Belgiji pet divizija, dok je Austro-Ugarska svoju frontu prema Italiji zaposjedala s gustoćom vojnika šest puta većom od one na fronti prema Rusiji. Gustoća rasporeda mitraljeza i artiljerije također je bila manja na istoku, a i ničija zemlja je bila šira. Ponekad je na ničijoj zemlji pasla stoka. Budući da je rizik bombardiranja bio manji i sustavi rovova nisu bili gusti, s većim posadama u prednjim linijama i manjim pokretnim rezervama u pozadini. Na istoku je bilo i manje željezničkih pruga, što je usporavalo dovođenje pojačanja. Ti su faktori olakšavali

10 Pruska je bila najveća savezna država njemačkoga Drugog Carstva (1871. - 1918.). Njemačko Carstvo bilo je ustrojeno kao federacija saveznih država, a Pruska je ostvarivala velik utjecaj na državnu politiku preko većega broja zastupnika u Bundesratu.

11 Galicija je nekadašnja austrijska krunska zemlja. Od Austro-ugarske nagodbe 1867. do 1918. bila je u austrijskom dijelu Monarhije. Danas je u južnoj Poljskoj.

12 Černjivci (Czernowitz), grad u zapadnoj Ukrajini. Od 1849. do 1918. bio je glavni grad Bukovine u sastavu Austro-Ugarske Monarhije.

13 Bukovina je od 1849. do 1918. bila austrijska krunska zemlja i nalazila se u austrijskom dijelu Monarhije. Danas je sjeverni dio Bukovine u sastavu Ukrajine, a južni u sastavu Rumunjske.

14 Detaljan opis donosi Nikola Tominac: "Przemysl se danas nalazi na jugoistoku Poljske na gornjem toku rijeke San. S poljskim utvrdama kod Jaroslava na sjeveru i Sanoka na jugu, zatvarao je ulaze u zapadnu Galiciju. Raskrižje je vrlo važnih željezničkih i cestovnih komunikacija. Austro-Ugarska je počela njezinu izgradnju u vrijeme Krimskog rata 1853. - 56. kao dvojnog mostobrana na rijeci San. Zbog svoje strateške važnosti uoči I. svjetskog rata spadala je u red najvećih austrougarskih pojasnih tvrđava. Zatvarala je pravac preko Brodija i Lavova, i štitila željezničku prugu Lavov - Krakov i planinske prijelaze na Karpatima između Dukle i Presova. S pojasnom tvrđavom Krakov, Przemysl je bio glavni oslonac austro-ugarske obrane u Galiciji." TOMINAC, "Ličani u 'Velikom ratu", 493. 
probijanje fronte, u čemu su Nijemci kod Gorlice-Tarnowa, odnosno Brusilov kod Lucka, i uspjeli, premda u različitim okolnostima." ${ }^{15}$

Detaljnije značajke, iako samo jednoga dijela, Istočnoga bojišta opisuje Tominac u radu "Ličani u 'Velikom ratu" u kontekstu determiniranosti ratnih operacija i borbenih djelovanja zemljopisnim odrednicama i toponimskim karakteristikama: "Na jugozapadu današnje Ukrajine, ili nekadašnje Galicije, nalazi se snažan i strateški važan planinski lanac Karpata, koji obuhvaća centralnu i jugoistočnu Europu. Proteže se u vidu izduženog i velikog luka od Bratislave pa sve do istočne Srbije. Oštro razdvaja Panonsku nizinu od ostalih važnih europskih nizina: Pribaltičke, Ukrajinske i Vlaške. Uglavnom je sastavljen od srednjih planina s nekoliko vrhova viših od 2.000 metara. Ulaz u Galiciju sa zapada osiguravalo je pet glavnih karpatskih prijelaza oko kojih će se težišno voditi sudbonosne bitke. Zbog svog geostrateškog značaja za vrijeme Prvoga svjetskog rata, Galicija će postati jednim od najvećih bojišta. Ona je ključ za ruski ulazak u Panonsku nizinu, ali i za obranu od napadača sa Zapada. Obrana Galicije predstavljala je poseban izazov za Dvojnu monarhiju. Zbog nedostatka povoljnih prirodnih obrambenih objekata - osim karpatskog gorja - Austro-ugarski vojni stratezi smatrali su je teško branjivom, bez obzira na pojedine tokove velikih rijeka." ${ }^{16}$

Ratne operacije i borbena djelovanja na Istočnom bojištu trajali su od siječnja do kraja listopada, iako su pojedini incidenti i otvaranje vatre kao i prebjezi s jedne i druge strane zabilježeni i tijekom studenoga i prosinca 1915. godine. Na Istočnom bojištu odigralo se nekoliko velikih bitaka: “Zimska bitka za Karpate” od 26. siječnja do 26. travnja, zimska bitka na Mazurskim jezerima, ofenziva kod Gorlica-Tarnówa i proboj ruskih položaja od 2. svibnja do 22. lipnja, združena ljetna ofenziva njemačke i austrougarske vojske u Poljskoj i njemačke vojske u baltičkim zemljama, nakon čega je uslijedilo "Veliko povlačenje ruske vojske" od 13. srpnja do 20. rujna, te naposljetku "Crno-žuta ofenziva" austrougarske vojske koja je započela 26. kolovoza, a borbena djelovanja prestala su 30. rujna. Ta je ofenziva završila porazom austrougarske vojske i gubitkom dijela osvojenoga teritorija uslijed ruskih protunapada.

U odnosu na početnu crtu bojišnice s početka 1915., konačna crta na kraju godine znatno se pomaknula: približno 500 kilometara prema istoku u odnosu na svoju najistureniju početnu zapadnu točku kod Płocka ${ }^{17}$ u ruskoj Poljskoj (današnja Poljska) do Dubna ${ }^{18}$ u Rusiji (današnja Ukrajina), te se protezala

15 STEVENSON, 1914. - 1918., 304.

16 TOMINAC, "Ličani u 'Velikom ratu”, 492.

17 Płock je grad u srednjoj Poljskoj na rijeci Visli sa 126675 stanovnika. Administrativno pripada Mazovjeckom vojvodstvu, najvećem od 16 poljskih vojvodstava.

${ }_{18}$ Dubno je grad u zapadnoj Ukrajini na rijeci Ikvi u oblasti Rivna. Administrativno je središte okruga Dubno s 38037 stanovnika. 
crtom Riga $^{19}$ - Daugavpils ${ }^{20}-$ Baranaviči $^{21}-$ Dubno $^{22}$ - Ternopilj ${ }^{23}$ - Vikno $(\text { Okna })^{24}$. U prosincu 1915. sučelice je uzduž cijele bojišnice stajalo sedam njemačkih armija (šest na sjevernom dijelu bojišnice, jedna na južnom) i tri austrougarske s jedne strane te devet ruskih armija s druge strane. Precizan broj vojnika, časnika i ratne tehnike (topova, artiljerije, strojnica itd.) zajedno s nekim podacima vezanim za opskrbu naveli su autori čiji će se radovi proučavati u ovom radu te će ti brojevi i podaci biti izneseni, analizirani i uspoređivani.

\section{Metodologija radova o Istočnom bojištu 1915. godine}

Ti radovi sadržavaju mnoge korisne podatke uz navođenje brojnih primarnih i sekundarnih izvora. U njima se obrađuju različiti aspekti tih događaja (politički, vojni, gospodarski i društveni). Većina autora nastoji detaljnije analizirati događaje na Istočnom bojištu 1915., a ne isključivo u kontekstu cijeloga Prvoga svjetskog rata. Neki su se autori specijalizirali za Istočno bojište fokusirajući se na vojnu komponentu, a drugi su imali sveobuhvatni pristup, pa njihova analiza obuhvaća širi kontekst, a vojna komponenta jedna je od sastavnica njihova metodološkoga diskursa, a ne isključivi predmet istraživanja. Dakle, ti radovi "nisu u istom rangu", pa se i ne mogu uspoređivati u istoj kategoriji.

Kako im je svima zajednički naglasak na "novim spoznajama i pogledima" u rješavanju pojedinih važnih historiografskih pitanja vezanih za Prvi svjetski rat, bitno je istaknuti i različite položaje s kojih te dvije historiografije obrađuju pojedina pitanja. Britanska je historiografija u mnogim pogledima, u ovom smislu, ispred hrvatske jer je prethodno riješila brojna važna pitanja od neposrednoga interesa za britansku povijest (sudjelovanje britanskih jedinica na Zapadnom i drugim bojištima, precizan broj poginulih, ranjenih, zarobljenih i nestalih britanskih vojnika i časnika, ekonomski aspekti i učinci rata na Britaniju, političke posljedice ishoda rata itd.). Hrvatska je historiografija tek na početku toga procesa, iz mnogih razloga: historiografska politika dviju jugoslavenskih država, nedostupnost izvora i literature, mali

\footnotetext{
19 Riga je danas glavni grad Latvije sa 720 tisuća stanovnika i kulturni, obrazovni, politički, financijski, komercijalni i industrijski centar Baltika. Nalazi se na ušću rijeke Daugave u Baltičko more, u južnom dijelu Riškoga zaljeva. Godine 1915. bila je u sastavu carske Rusije i važno željezničko središte.

${ }^{20}$ Daugavpils je grad u jugoistočnoj Latviji, drugi po veličini u Latviji, nakon glavnoga grada Rige. Nalazi se 230 kilometara jugozapadno od Rige na obalama rijeke Daugave, prema kojoj je i dobio ime, koje doslovno znači "grad na Daugavi".

${ }^{21}$ Baraniviči je grad u zapadnoj Bjelorusiji, udaljen 195 kilometara od Bresta, a 1915. također je bio važno željezničko središte i opskrbni put ruske vojske.

${ }^{22}$ U borbama u ljeto i ranu jesen 1915. njegova obrambena tvrđava potpuno je uništena.

${ }^{23}$ Ternopilj (Tarnopol), grad u zapadnoj Ukrajini, središte Ternopiljske oblasti. Nalazi se 90 kilometara južno od Dubnog.

${ }^{24}$ Vikno (Okna) je selo u zapadnoj Ukrajini u okrugu Horodenka u oblasti Ivano-Frankivsk, 70 kilometara južno od Ternopilja.
} 
broj specijaliziranih radova o hrvatskim vojnicima koji su sudjelovali u ratnim operacijama na Istočnom bojištu, materijalni uvjeti i nedostatak državne ili institucionalne potpore te zanimanje povjesničara za Drugi svjetski rat ili neke druge teme iz XX. stoljeća, potvrđujući tezu o "zaboravljenom ratu" pri nedostatku interesa za bavljenje Prvim svjetskim ratom.

Zato su, da bi se naglasila važnost proučavanja najnovije britanske i hrvatske historiografije o Prvom svjetskom ratu i pritom istaknula praktična korist od takva rada, mnogi navodi korisni u smislu da upućuju hrvatskoga istraživača da preuzme i iskoristi metodologiju i podatke iz ovdje obrađenih radova britanskih autora za donošenje zaključaka i rasvjetljavanje pojedinih pitanja važnih u hrvatskoj historiografiji. Isto tako, mnogi korisni podaci u radovima hrvatskih autora, kao i korištena metodologija, mogu poslužiti kao dobra dopuna nekim historiografskim navodima britanskih autora, jer i s njihove strane postoji očigledan interes za komplementarnu tematiku ovoga segmenta Prvoga svjetskog rata.

Historiografski pomak u proučavanju Prvoga svjetskog rata u preglednom razdoblju od 2014. do 2017. godine

Stanje kakvo je bilo 2014., dakle na početku razdoblja koje se ovdje tematski obrađuje, opisuje Vijoleta Herman Kaurić u radu "The First World War in Croatia - More or less known facts": "U posljednjih 15 i nešto godina broj historiografskih studija i doktorskih radova na temu Hrvatske tijekom Prvoga svjetskog rata znatno se povećao, ali napredak je bio malen. To je posebno vidljivo kada se usporedi s opsegom istraživanja u zemljama koje su nekad činile dio Austro-Ugarske Monarhije (pogotovo Austriji) ili sa Srbijom. Do sada se hrvatska javnost i historiografija fokusirala na Drugi svjetski rat i/ili na Domovinski rat... Osim nedostatka interesa, postoji i nedostatak specijaliziranih istraživača. Zbog svega toga razdoblje Prvoga svjetskog rata ostaje jednim od najmanje istraženih razdoblja hrvatske povijesti, iako se nalazi u području interesa istraživača specijaliziranih za povijest XIX. stoljeća - kraj rata i raspad Austro-Ugarske Monarhije također označava kraj razdoblja u kojem je Hrvatska bila pod habsburškom vladavinom, a koje je trajalo gotovo četiri stoljeća." ${ }^{25}$

Taj je rad objavljen 2014. prilikom obilježavanja stogodišnjice izbijanja rata. Iste je godine objavljena knjiga Prvi svjetski rat. Čitanka-priručnik... skupine hrvatskih autora namijenjena osnovnim školama i gimnazijama da bi učenicima bolje približila tematiku Prvoga svjetskog rata. Premda sadržava brojne korisne podatke i bogat vizualni sadržaj, i u njoj je vidljiv istaknuti navod Herman Kaurić o nedostatku specijaliziranih radova, posebno u dijelu u kojem analitički pristup nije proveden u pogledu stradalih hrvatskih vojnika prema pojedinim godinama na pojedinim bojišnicama Prvoga svjetskog rata na kojima su ratovali.

${ }^{25}$ HERMAN KAURIĆ, "The First World War in Croatia", 8-9. 
Stanje u hrvatskoj historiografiji bitno se popravilo u iduće tri godine objavom nekoliko znanstveno-publicističkih radova o Istočnom bojištu, od kojih se dva obrađuju ovdje. No o događajima na Istočnom bojištu 1915. nema uopće podataka u novoj knjizi sinteze hrvatske povijesti Dinka Šokčevića Hrvatska od stoljeća 7. do danas izdanoj u Zagrebu 2016. godine. U njoj autor posvećuje stanovit prostor Hrvatskoj u Prvom svjetskom ratu (str. 346 - 359), ali u pogledu Istočnoga bojišta donosi samo općenito i nepotpuno lokalitet bitaka u kojima su sudjelovali hrvatski vojnici (Galicija). ${ }^{26}$ No ne radi se o previdu, nego o činjenici da Šokčević nije spomenuo te događaje jer mu nisu bili dostupni specijalizirani radovi o tome niti su stanje iznosili autori u dosadašnjim hrvatskim sintetskim pregledima u vezi s Prvim svjetskim ratom općenito, a posebno Istočnim bojištem. ${ }^{27} \mathrm{Na}$ kraju Šokčević donosi podatak o broju ubijenih i ranjenih: "Na bojišnicama Prvog svjetskog rata poginulo je ukupno 190.000 vojnika mobiliziranih na području Hrvatske i Bosne i Hercegovine, uz više stotina tisuća ranjenih i jednako toliko zarobljenih na ruskoj i talijanskoj bojišnici" ${ }^{28}$, ali iz tih općih podataka teško je ustanoviti točan broj poginulih, ranjenih, zarobljenih ili nestalih hrvatskih časnika i vojnika na Istočnom bojištu 1915. godine.

Stoga je i više nego opravdano analizirati te događaje proučavajući najnovije radove britanske i hrvatske historiografije koji nude obilje podataka pomoću kojih bi se mogao procijeniti približno točan broj stradalih (poginulih, ranjenih, zarobljenih ili nestalih) hrvatskih časnika i vojnika, koji je, kada se uzme u obzir činjenica o strahovitim ljudskim gubicima, zapravo velik u cjelokupnom udjelu ljudskih gubitaka hrvatskih zemalja u Prvom svjetskom ratu.

U radu “The First World War in Croatia” Herman Kaurić iznijela je nekoliko zanimljivih navoda i neke opće podatke koji mogu poslužiti kao polazna točka daljnjim istraživanjima: "Danas postoji samo opće znanje na kojim su bojišnicama hrvatske bojne bile aktivne. Najprije su bile poslane u Srbiju, zatim u Rusiju, tj. na teritorij današnje Ukrajine (Bukovina i Galicija), i naposljetku na Talijansko (Sočansko) bojište, gdje su gotovo sve hrvatske jedinice bile razmještene kasne 1917. / rane 1918. godine. Otprilike je poznato koliko su vremena pojedine jedinice provele na bojišnicama. Neke od njih bile su bolje istražene zahvaljujući naporima lokalnih entuzijasta, ali općenito govoreći, Hrvatska zna vrlo malo o sudbini svojih vojnika u Prvom svjetskom ratu." ${ }^{29}$ Takvo je bilo stanje prema saznanjima autorice 2014. godine.

26 "Hrvatske domobranske pukovnije i hrvatske pukovnije zajedničke vojske ratovale su unutar i izvan granica Monarhije, prvo u Srbiji, potom u Galiciji, a kasnije na talijanskoj bojišnici... u zapovjedništvu austro-ugarske vojske djelovalo je više hrvatskih generala (odnosno generala rođenih u Hrvatskoj ili Bosni i Hercegovini). Najpoznatiji od svih bio je Svetozar Borojević (premda pravoslavac, deklarirani Hrvat), koji se istaknuo u bitkama na Soči." ŠOKČEVIĆ, Hrvatska od stoljeća 7 . do danas, 347.

${ }^{27}$ Primjerice: Ivo Goldstein, Hrvatska povijest (Zagreb: Novi Liber, 2013), Dušan Bilandžić, Hrvatska moderna povijest (Zagreb: Golden marketing, 1999), Dragutin Pavličević, Povijest Hrvatske (Zagreb: Naklada Pavičić, 1994).

28 ŠOKČEVIĆ, Hrvatska od stoljeća 7. do danas, 347.

${ }^{29}$ HERMAN KAURIĆ, “The First World War in Croatia”, 11. 
U međuvremenu se ipak dogodio važan pomak nabolje u hrvatskoj historiografiji i objavljena su dva rada koja se specijalističkim pristupom bave sudbinom hrvatskih vojnika na Istočnom bojištu: "Ličani u 'Velikom ratu'. Zimska bitka za Karpate, siječanj-travanj 1915" vojnoga povjesničara Nikole Tominca i Hrvatski grobovi 1914. - 1918. Karpati, Galicija, Bukovina Jevgenija Paščenka, koji će biti pobliže analizirani u nastavku. Može se dakle zaključiti da je rad Herman Kaurić poslužio kao poticaj istraživačima da se bave tematikom stradalih hrvatskih vojnika na Istočnom bojištu i za otkrivanje novih izvora, nedostupnih u domaćim institucijama i dosadašnjoj literaturi. Autorica je konstatirala: "Sto godina nakon završetka rata neki od potomaka vojnika traže podatke o svojim djedovima i pradjedovima. Mnogi od njih ne znaju čak ni u kojoj su jedinici njihovi preci služili, ali obiteljske priče o njihovim pogibijama na Soči ili u Rusiji bile su sačuvane generacijama. Neki od njih pronašli su požutjele fotografije vojnika koje ne prepoznaju ili njihove zapise s bojišnice te se sada pitaju postoji li više informacija o tim ljudima. Za većinu će odgovor biti negativan, ali smatram to vrijednim pokušati saznati” ${ }^{30}$ i zapravo otvorila zanimljivo pitanje hrvatskoj historiografiji - pitanje sudbine brojnih pripadnika oružanih snaga austrougarske vojske hrvatskoga podrijetla na Istočnom bojištu.

Odgovor na to pitanje nije bilo potrebno dugo čekati. Paščenkov rad Hrvatski grobovi 1914. - 1918. dao nam je u malom, ali ohrabrujućem primjeru pojedinačne ljudske sudbine nadu da će se sudbina svih ili barem većega dijela hrvatskih vojnika poginulih na Istočnom bojištu konačno rasvijetliti: "Kao primjer ove problematike može nam poslužiti pismo koje je autor zaprimio od Denisa Štuleca iz Samobora. Naime, Denis Štulec je potaknut obilježavanjem stogodišnjice početka Prvoga svjetskoga rata, odlučio istražiti sudbinu poginulog pradjeda Stjepana Štuleca, rođenog 1896. u Samoboru, a koji je poginuo 1. kolovoza 1917. u Schipenitz ili Szypynci. U odgovoru iz Arhiva u Beču saznao je da pradjed nije poginuo kao pripadnik zagrebačke 25. domobranske pješačke pukovnije, nego kao pripadnik sisačke 27 . domobranske pješačke pukovnije." 31

Iz izloženoga je vidljivo da bi se metodologija primijenjena na jednom individualnom primjeru znatiželjnoga potomka hrvatskoga vojnika stradalog na Istočnom bojištu mogla iskoristiti za rasvjetljavanje sudbine ako ne svih, onda preostalog velikog broja stradalih (poginulih, zarobljenih, nestalih) hrvatskih časnika i vojnika.

Koliko je opravdana teza o inferiornosti austrougarske vojske u odnosu na njemačku i rusku vojsku?

U prvoj skupini radova koji se bave vojnom poviješću, Bassett u knjizi For God and Kaiser zauzima pozitivan stav prema cjelokupnoj ocjeni borbene

\footnotetext{
${ }^{30}$ Isto, 20.

${ }^{31}$ PAŠČENKO, Hrvatski grobovi 1914. - 1918., 79.
} 
spremnosti austrougarske vojske na Istočnom bojištu 1915. godine. U pogledu austrougarske vojske u Prvom svjetskom ratu općenito, a posebno na Istočnom bojištu, autor je u svojim stavovima zapravo kontradiktoran. Na nekim mjestima Bassett "naginje" stavovima britanskih kolega Buttara, Lievena i Watsona, koji drže da je austrougarska vojska bila inferiorna u odnosu na njemačku i rusku, a na drugima izvodi potpuno suprotne zaključke od njih.

Najprije zastupa tezu da je austrougarska vojska, bez obzira na niz katastrofalnih poraza i velike ljudske i materijalne gubitke u prvim mjesecima rata tijekom jeseni i zime 1914., zapravo bila u jako dobrom stanju na Istočnom bojištu 1915. godine. Tako započinje 23. poglavlje knjige ("1915. - 1916. Bajunete u Dolomitima”, str. 480 - 497) ovim riječima: "Nova godina pokazat će se još izazovnijom za carske i kraljevske oružane snage nego 1914. godina. Sposobnost Carstva da se oporavi od katastrofa 1914. na dvije bojišnice te čak suoči s novim prijetnjama pokazala je da još uvijek može voditi rat, iako kao mlađi partner sve više dominantnoga njemačkoga ratnog stroja. Uz novu bojišnicu protiv susjeda na jugu, Italije, godinu obilježava i odluka da se pošalju dvije baterije s 813 topnika i 22 časnika u Palestinu da bi se podupro osmanski napor protiv Britanaca." ${ }^{2}$

U tom diskursu Bassett nastavlja analizu smatrajući da je Conrad von Hötzendorf ${ }^{33}$ bio kreator plana i glavni strateg ofenzive i proboja kod Gorlica-Tarnówa $^{34}$, ali da su ofenzivi ipak najviše pridonijeli Nijemci svojim taktičkim iskustvom sa Zapadnoga bojišta. ${ }^{35}$ Prema njegovim podacima, od ruskih žrtava bilo je 210 tisuća ubijenih (od ukupno 250 tisuća ljudi), a zarobljenih vojnika bilo je samo 14 tisuća. ${ }^{36}$ Broj ruskih zarobljenika u spomenutoj ofenzivi koji iznosi Bassett jako se razlikuje od brojeva koje donose drugi autori u ovoj skupini radova koji se bave vojnom poviješću. Primjerice, Buttar u knjizi Germany Ascendant kaže sljedeće: "Sve u svemu, broj zarobljenika bio je bez pretjerivanja viši od 240 tisuća samo u sektoru 11. armije, penjući se do preko

32 BASSETT, For God and Kaiser, 480.

33 Franz Conrad von Hötzendorf (1852. - 1925.), austrijski general i načelnik glavnoga stožera austrougarske vojske od početka rata do kraja 1917., kada je smijenjen. Iako je nominalni vrhovni zapovjednik austrougarske vojske na Istočnom bojištu 1915. bio nadvojvoda Friedrich, de facto je njezin planer i vrhovni zapovjednik u svim borbenim operacijama na tom bojištu tijekom 1915. bio Conrad von Hötzendorf.

34 Ofenziva Gorlice-Tarnów je vojna operacija njemačke i austrougarske vojske kod Gorlica i Tarnówa u središnjoj Galiciji (današnja južna Poljska). Započela je 2. svibnja 1915., a završila 22. lipnja 1915. godine. Sudjelovale su njemačka 11. armija pod zapovjedništvom generala Mackensena te austrougarske 2., 3. (pod zapovjedništvom prvotno Borojevića, zatim Puhalla) i 4. armija pod zapovjedništvom nadvojvode Friedricha, protiv ruske 3. armije pod zapovjedništvom generala Dimitrieva. Ofenziva je završila velikom pobjedom Centralnih sila.

35 "Ofenziva je započela u stilu Zapadnoga bojišta, četverosatnim bombardiranjem intenzitetom bez presedana na Istočnom bojištu. Rusi su pripremili svoje prve linije rovova, ali njihove druge i treće linije nisu bile ukopane te ih je za jedan sat bombardiranje izbrisalo. Bez potpore i trpeći udarce borbene tehnike, Rusi su se pokušali povući, ali uhvatilo ih je još baražne vatre. Rusi su procijenili da je unutar tri sata palo 700 tisuća granata." BASSETT, For God and Kaiser, 488.

36 Isto. 
400 tisuća ako se uzmu u obzir bočne armije i one na Dnjestru. Ruske 3. i 8. armija bile su efektivno eliminirane kao važne formacije i krajnji cilj njemačkih i austrougarskih snaga - zadati odlučujući udarac koji bi eliminirao prijetnju ruskih ofenziva - postignut je u manje od dva mjeseca." ${ }^{37}$

Na drugom mjestu Bassett smatra da je austrougarska vojska bila sposobna samostalno pobijediti Ruse, pa zaključuje: "Jedini uspjeh koji je talijanski ulazak u rat donio Antanti jest premještanje mnogih elitnih austrijskih alpskih postrojbi s bojišnice u Galiciji. Da su one bile prisutne tijekom posljedica Conradove pobjede kod Gorlica, ruski kolaps možda bi nastupio otprilike godinu prije." ${ }^{38}$ No indikativno je da se ipak na kraju vraća svojem prijašnjem stavu da su očiti mnogobrojni nedostaci austrougarske vojske onemogućavali pobjedu u ratu. Te nedostatke ne nabraja taksativno - kao što to čine primjerice Buttar, Freivogel i Tominac, jer su njihovi radovi tematski drukčiji, pa u tom pogledu zahtijevaju detaljniju analizu - nego se oslanja na dokazane činjenice i citira Ericha von Falkenhayna ${ }^{39}$, pokazujući na taj način, a ne iskazujući ga eksplicitno, osobni stav prema tom pitanju: "Carska i kraljevska vojska izgubila je 230886 ljudi u propaloj 'Crno-žutoj ofenzivi'. Od toga je zarobljenika bilo više od 100 tisuća. Austrijske snage na Istočnom bojištu smanjene su s pola milijuna na četvrt milijuna. 'Crno-žuta' je dokazala jednom i zauvijek da Austrija, Falkenhaynovim riječima, 'nikad neće pobijediti Rusiju.' 40

Međutim, da bi se pravilno razumjelo Bassetta i shvatilo pravo značenje njegove knjige u kojoj se prikazuje karakter habsburške vojske, koja se još pune tri godine od završetka događaja na Istočnom bojištu 1915. "nije slomila”, potrebno je pozornost posvetiti navodu u kojem autor definira prvenstveni cilj radi kojega je ta vojska ustrojena: "Oružane snage postojale su da bi služile dinastiji. Vojska bi, ako je potrebno, branila Habsburgovce od svoje vlastite aristokracije. Sve do prestanka njezina postojanja 1918., vojni sastav i način ratovanja uvijek su bili podređeni interesima kuće Habsburg. To je odražavala vojna strategija. Nijedna austrijska armija nije smjela riskirati uništenje svojih protivnika ako je postojao i najmanji rizik da uništi samu sebe. Avanturističke taktike bile su prijetnja dinastiji. Pretjerana odvažnost ili spontano vojno kockanje nisu bili dio habsburškoga ratnog pravilnika. Vojska je uvijek morala biti u stanju boriti se drugi dan, braniti dinastiju... Zahvaljujući toj strategiji habsburška se vojska u gotovo svakom ratu koji je vodila oporavila od početnih poraza, podignula razinu svoje izvedbe i postala mnogo učinkovitiji borbeni stroj. Između 1620. i 1918. ona je pobijedila u više od 350 velikih bitaka, što je broj mnogo veći od broja njezinih poraza." ${ }^{41}$ Zaključno u vezi s tom knjigom može se reći da autor drži da je austrougarska vojska postigla

\footnotetext{
37 BUTTAR, Germany Ascendant, 264.

38 BASSETT, For God and Kaiser, 494.

39 Erich von Falkenhayn (1861. - 1922.), njemački general i načelnik glavnoga stožera njemačke vojske od rujna 1914. do kolovoza 1916. godine.

40 BASSETT, For God and Kaiser, 495.

${ }^{41}$ Isto, 4.
} 
znatne uspjehe u borbama na Istočnom bojištu 1915. te da bi u drukčijim političkim okolnostima (neulazak Italije u rat na strani Antante) ona postigla i odlučujuću pobjedu. U tom se pogledu Bassett najviše odmaknuo od do sada ustaljenoga historiografskog stava o austrougarskoj vojsci kao "drugorazrednoj oružanoj sili”.

Prit Buttar u tom je pogledu konkretniji. Osim što se metodološki šire i detaljnije bavi tijekom svake pojedine vojne operacije na Istočnom bojištu 1915., njegova se analiza temelji, među ostalim, i na mnogim izjavama neposrednih očevidaca ratnih operacija: od "običnih vojnika" do zapovjednika na terenu. Usto je priložio razmišljanja i zapise zapovjednika u stožerima vojski i monarha Franje Josipa I. i Vilima II. o tim vojnim operacijama. Buttar izvodi specifičan zaključak: načelno se slaže s tezom o inferiornosti austrougarske vojske, ali takav zaključak ne izvodi izravno, nego komparativnom analizom nastoji dokazati da su sve zaraćene vojske u nekom trenutku bile u specifičnom suodnosu u kojem su se čas nalazile u podređenom, a čas u nadređenom položaju. To dokazuje iznošenjem općenitoga i kroničnoga problema svih zaraćenih vojski na Istočnom bojištu: nedostatak naoružanja, streljiva ${ }^{42}$ i druge opreme, povezano s problemima opskrbe i komunikacije. Te faktore smatra glavnim uzročnicima konačnoga ishoda na Istočnom bojištu 1915., koji je završio bez pobjednika. Dakle, materijalni nedostaci koji su bitno utjecali na borbenu spremu vojske i umanjivali njezinu efektivnu (operativnu) moć nisu bili, prema njegovu mišljenju, isključivo austrougarski problem. Od istoga sindroma patila je i ruska vojska, a u pojedinim prilikama, iako ne često i toliko izraženo kao austrougarska i ruska, i njemačka vojska, uza sav mit o tehničko-organizacijskoj perfekciji "njemačkoga ratnog stroja".

U prilog tome kaže: "Rane 1915. arsenal u Steyru povećao je proizvodnju s 2000 pušaka mjesečno u rujnu 1914. na 32 tisuće, ali je trebalo vremena da ta dodatna proizvodnja dođe do crte bojišta. Strojnice, koje su mnogi tradicionalno orijentirani časnici prije rata smatrali tek previše složenim igračkama, sada su bile široko držane kritično važnima i sve su vojske nastojale povećati njihov broj po bojnama. Isprva se čak i nadomještanje izgubljenoga oružja u prvim mjesecima rata pokazalo teškim. Nedostajalo je i odora i čizama. Tijekom marširanja kroz Galiciju u prvim tjednima rata mnogi austrougarski i ruski vojnici odbacili su teške kapute i, kako je vrijeme postalo hladnije, manjak odgovarajuće zimske odjeće - što će se vidjeti pogotovo u Karpatima višestruko je povećao broj stradalih. Čak je i dostava običnih odora bila problematična; neki austrougarski rezervisti bili su otpremljeni u civilnoj odjeći,

${ }_{42}$ Taj argument ističe većina autora u pogledu nedostataka na Istočnom bojištu. No oni te nedostatke navode samo načelno i općenito. Primjerice, Zvonimir Freivogel iznosi posljedice neuspjele “Crno-žute ofenzive” iz listopada 1915. godine ovako: „Rusi su pak uz 'austrougarsku pomoć' uspjeli riješiti problem nedostatne proizvodnje i opskrbe vojnim tvarivom: oružjem zarobljenim tijekom protuofenzive uspjeli su naoružati dva vojna zbora! Počela je proizvodnja metaka u austrougarskim kalibrima, ukupno 37 milijuna komada, što je bilo nužno potrebno, jer su ruski vojnici 'prekomjerno trošili' streljivo: dok je francuski vojnik prosječno ispalio 30 metaka mjesečno, a britanski 50, Rus bi utrošio 150.” Vidi: FREIVOGEL, Austrougarska vojska, 208. 
samo s crnom trakom oko ruke da bi se naznačio njihov status boraca." ${ }^{43}$ Malo preciznije u vezi s tim dalje piše: "Puna oprema austrougarskoga pješaka težila je otprilike 33 kilograma i čak kada je bilo moguće da novaci dobiju puni komplet odjeće, kaput, šljem, lopatu, pušku itd., mnogi od njih, nespremni marširati pod takvim teretom, jednostavno su odbacili većinu toga." ${ }^{44}$

Autor daje uvid i u situaciju u ruskoj vojsci: "Ruska industrija jednostavno nije bila sposobna proizvoditi dovoljno granata; u rujnu je francuska procjena bila da ruske tvornice mogu proizvesti 35 tisuća granata mjesečno, a dnevna potrošnja bila je 45 tisuća rundi." ${ }^{45}$ Zaključno u vezi s nedostacima na nekoliko mjesta navodi zapise ruskoga generala Brusilova ${ }^{46}$, a najbolji je primjer onaj s početka svibnja 1915., neposredno prije austrougarskoga i njemačkoga proboja kod Gorlica-Tarnówa, kada je ruska vrhovna komanda očekivala od Brusilova da pokrene odlučujući napad na austrougarske snage i ostvari konačnu pobjedu nad njima: "Stalno opadanje opskrbe streljivom jako me zabrinjavalo. Imao sam manje od 200 rundi (po topu). Pokušao sam dobiti informaciju kada bi se moglo osloniti na opskrbu dovoljnom količinom topova i streljiva te me, na moje razočaranje, osoblje jugozapadnoga bojišta obavijestilo da se poboljšanje na ovom području ne može očekivati prije jeseni 1915., a i to je bilo uvjeravanje u koje ni oni sami nisu vjerovali. S bijednom zalihom streljiva i bez nade da ću ga dobiti, bilo je krajnje besmisleno poduzeti aktivne korake napretka u mađarsku ravnicu. Zapravo, streljiva za puške bilo je dovoljno za samo jednu bitku, a onda bi vojska bila potpuno bespomoćna, u nemogućnosti da napreduje dalje i suočena s velikim teškoćama povlačeći se kroz karpatske planine naoružana samo hladnim oružjem." ${ }^{47}$

Buttar je želio naglasiti da nedostatak naoružanja i opreme nije bio problem isključivo austrougarske vojske, nego zajednički negativni faktor koji je opterećivao borbenu spremnost i austrougarske i ruske vojske, a u konačnici bitno utjecao na krajnji ishod.

Najbolji doprinos analizi borbene spremnosti austrougarske vojske u pojedinim bitkama autor je na nekoliko mjesta dao u prikazima njezine efektivne, stvarne snage na terenu u odnosu na onu zabilježenu u vojnim i službenim publikacijama. Drugim riječima, nastojao je dokazati da brojke na papiru nisu odgovarale stvarnom stanju u borbenim uvjetima, dodatno opterećenim oskudicom u naoružanju i hrani. U tom se kontekstu može realnije sagledati borbena moć austrougarske vojske u odnosu na rusku. Najbolji je primjer vidljiv

${ }^{43}$ BUTTAR, Germany Ascendant, 21.

${ }^{4}$ Isto, 62 .

${ }^{45}$ Isto, 21.

${ }^{46}$ Aleksej Aleksejevič Brusilov (1853. - 1926.), ruski general i zapovjednik 8. ruske armije na jugozapadnom ruskom bojištu. Najpoznatiji kao tvorac nove ofenzivne taktike primijenjene $\mathrm{u}$ ofenzivi na Istočnom bojištu 1916., nazvanoj po njemu Brusilovljevom ofenzivom. Buttar ga drži najboljim ruskim zapovjednikom: "U nedostatku opskrbe svih vrsta, improvizirao je najbolje što je mogao, pokazujući da je vjerojatno najbolji ruski zapovjednik svojega doba.” Isto, 36.

47 Isto, 181. 
u ovom navodu: "Iako je Kusmanek ${ }^{48}$ prijavio da je njegova borbena snaga bila 84 tisuće ljudi, manje od 15 tisuća njih bili su redovni vojnici. Ostali su bili relativno neiskusni i slabo uvježbani rezervisti Landsturma, čija je sposobnost da se nastave boriti suočeni s preprekama bila ograničena." ${ }^{49}$

Navodeći zapise njemačkih zapovjednika, Buttar je zapravo želio prikazati stvarnu efektivnu snagu austrougarske vojske. $\mathrm{U}$ tim je navodima vidljivo da su pojedini njemački generali sasvim različito gledali na svoje saveznike. Iz zapisa generala Ludendorffa ${ }^{50}$ prilikom posjeta zajedničkim austrougarskim i njemačkim pripremama za prvu karpatsku ofenzivu iz siječnja 1915. dobivamo uvid u ocjenu karaktera austrougarske vojske. Iz njega se može iščitati pravo Ludendorffovo mišljenje o cjelokupnoj austrougarskoj državi i njezinim ratnim potencijalima, koje je sudio prema civilizacijskoj razini sela koje je posjetio na bojišnici u Karpatima: "Nedovoljno je bilo napravljeno za trupe, od izgradnje položaja do osiguranja smještaja. Mnogo se toga moralo nadoknaditi. Prolazeći kroz planinske šume, naišao sam na ispostavu. Vojnik me pozdravio na stranom jeziku, ne sjećam se više kojem. Ni časnici Carske i kraljevske vojske koji su me pratili nisu razumjeli. Tako sam dobio dojam o teškoćama s kojima se suočavala ova vojska. One su uvelike pojačane jer su narodi u bojnama pomiješani u nastojanju da se poboljša njihova pouzdanost. Češke i rumunjske bojne prešle su neprijatelju. Te su narodnosti sada raspoređene po brojnim bojnama. Te mjere nisu pomogle. Pogotovo su smanjile vrijednost hrabrih ugarskih i učinkovitih austrijskih bojni, a povećale jezične teškoće do nevjerojatnoga stupnja. Ovdje isto... Dobio sam uvid u krajnju zaostalost svih ljudi koji ne pripadaju vladajućoj rasi... Imao sam isti dojam s putovanja u sela Hutzela (etnička grupa koja živi u Karpatima). Još uvijek se sjećam krhkosti kuća tih nesretnih ljudi. Koliko su drukčije prilike u Njemačkoj zahvaljujući mjerama njihovih gospodara, i koliko su kulturniji i napredniji s nama, uspoređujući s Austro-Ugarskom. Austro-Ugarska je opetovano podbacila u toliko toga; kao saveznička sila, morali smo znati što nas je ometalo. Da su Dvojna Monarhija i Carska i kraljevska vojska postigle samo pola onoga što je Njemačka opravdano i pravedno od njih očekivala, ne bi njemačke jedinice u tolikom broju bile potrebne kao pojačanja za austrougarsko bojište; imali bismo više raspoloživih jedinica za zapad u ovom razdoblju... u konačnici, naša je krivnja što smo sklopili savez s državama u opadanju kao što su Austro-Ugarska i Turska. U Radomu je Židov rekao jednom od mojih ljudi da ne shvaća zašto bi se tako snažna i životna nacija kao Njemačka vezivala lancima za leš. Imao je pravo, ali Njemačka nije mogla steći ratne saveznike snažne volje... Prvi sam put saznao o okolnostima u Austro-Ugarskoj tijekom rata, nemajući prije prilike za to. Začudilo me što vidim tako slabu državu. Naši mjerodavni

\footnotetext{
${ }^{48}$ Hermann Kusmanek von Burgneustädten (1860. - 1934.), austrougarski general i vojni zapovjednik tvrđave Przemyśl.

49 BUTTAR, Germany Ascendant, 60.

${ }^{50}$ Erich Ludendorff (1865. - 1937.), njemački general i vojni teoretičar. Godine 1915. na Istočnom bojištu obnašao je dužnost načelnika glavnoga stožera njemačke 11. armije, koja se nalazila u Istočnoj Pruskoj pod zapovjedništvom generala Hindenburga.
} 
odjeli sigurno su znali da je Dvojna Monarhija postala bolesnik Europe, ali nisu izveli pravilne zaključke." ${ }^{51}$

Suprotno tom mišljenju, navodi zapažanja koja je zapovjednik njemačke 11. armije general Mackensen napisao u svoj dnevnik 6. svibnja 1915. godine: "Austrijske su se trupe dobro borile u bitkama. Nevjerojatno je vidjeti kako blizina Pickelhaubea ${ }^{52}$ ima učinak na njihovo držanje tijekom bitke. Njihovo pouzdanje u bitci ovisi o tome. Stvarni austrougarski vođa je Conrad von Hötzendorf, čovjek čiji su srce i um narasli s njegovim položajem. Nadvojvoda Josip Ferdinand dobar je vojnik; radi svoj posao predano i odlučno, predmete rješava odmah i stoga ga cijenim, kao i njegova podređenoga. General von Arz, koji zapovijeda VI. korpusom (sastavljenim od jedne austrijske i jedne ugarske bojne), dodijeljenim 11. armiji, pokazao se također kao vrlo vješt zapovjednik." ${ }^{33}$ Autor je zapravo tim navodima htio naglasiti da su i među najviše rangiranim njemačkim časnicima i zapovjednicima postojala potpuno suprotna gledišta na cjelokupnu ratnu situaciju.

Zatim istom tehnikom opisuje stanje u ruskoj vojsci prilikom povlačenja u ljeto i ranu jesen 1915. godine. Zanimljivost je u tome što autor zapravo ističe da je u tom trenutku austrougarska vojska čak bila i superiorna ruskoj. Nakon uspjeha Centralnih sila na svim sektorima bojišnice, "bez obzira na neslaganja zapovjednika, surova stvarnost na terenu bila je takva da je ruska vojska bila blizu točke slamanja... Mladi britanski časnik pri 3. armiji poslao je niz izvještaja britanskom vojnom atašeu Alfredu Knoxu, koji u to vrijeme nije bio s jedinicama na prvoj crti bojišnice: 'Ova je vojska sada bezopasna svjetina... Evo kakva je snaga pojedinih jedinica čak i nakon što su stigla pojačanja nakon 14. svibnja po stopi od 2000 do 4000 dnevno: 12. sibirska bojna, 18 časnika i 3000 ljudi; X. korpus, sve tri bojne zajedno 14 tisuća ljudi... XXIII. korpus izgubio je više od polovine snaga u napadu. Deveti korpus izgubio je 3500 ljudi u tri dana... nedostaje nam streljiva i topova. Svi shvaćaju beskorisnost slanja ljudi protiv neprijatelja, njih s njihovom artiljerijom, nas s našom... Svi kasniji napadi bili su čisto ubojstvo, jer smo napadali velike dijelove terena teškom artiljerijom bez odgovarajuće artiljerijske pripreme." ${ }^{54}$

Buttar zastupa tezu da su dva glavna razloga zbog kojih su austrougarske armije bile manje uspješne od svojih njemačkih saveznika. Prvi leži u doktrini ratovanja koju je njegovao načelnik glavnoga stožera austrougarske vojske Conrad von Hötzendorf. Prema autorovu mišljenju, ta se doktrina sastojala u naglašavanju ofenzivnoga djelovanja, prepuštanja odlučivanja niže rangiranim

\footnotetext{
51 BUTTAR, Germany Ascendant, 64.

${ }^{52}$ Pickelhaube (njem. picke, "šiljak", haube, "kaciga, šljem”), poseban oblik vojničke kacige sa šiljkom na vrhu koji je koristila najprije pruska vojska od sredine XIX. stoljeća, a poslije i pojedine druge vojske (ruska, američka). Taj oblik kacige tipičan je za njemačku pješadiju u Prvom svjetskom ratu. Od rujna 1915. njemačka pješadija nije upotrebljavala taj model jer zbog svoje konstrukcije nije pružao dovoljno zaštite vojnicima u rovovima, te zbog nedostatka materijala (kože) za izradu.

53 BUTTAR, Germany Ascendant, 204.

${ }^{54}$ Isto, 256.
} 
časnicima na terenu i tretiranju pojedinih jedinica kao da su u punoj snazi bez pravoga uvida u situaciju na terenu. ${ }^{55}$ Tako autor kaže da bi Conrad von Hötzendorf planirao ofenzivu potpuno nesvjestan da ne raspolaže brojčanim stanjem kakvo je bilo njemu prezentirano na papiru, potpuno zanemarujući borbenu spremnost (faktor iscrpljenosti ili morala) pojedinih jedinica. Takvim je postupanjem Conrad dolazio u sukob ne samo s ostalim austrougarskim zapovjednicima, pogotovo Borojevićem ${ }^{56}$ (što opetovano iznosi i Tominac u svojem radu), nego i sa svojim njemačkim saveznicima, pa ovako opisuje Conradovu reakciju na Borojevićev zahtjev za slanje pojačanja u prvoj karpatskoj ofenzivi" : "Conrad je odgovorio grdeći Borojevića što nije uspio pobijediti, uzimajući u obzir da je na raspolaganju imao 15 divizija suočenih sa samo 12 ruskih divizija. S divizijama čija je snaga bila svedena na snagu jedva bojne, i bez potpore artiljerije, Borojevićeva reakcija na to može se samo zamisliti. Odnosi između Conrada i Borojevića, nikada pretjerano dobri, još su se pogoršali. Realnost je bila takva da su Borojevićeve jedinice nestajale zastrašujućom brzinom. U četiri je dana V. korpus - dio Gruppe Puhallo - prijavio da je njegova borbena snaga spala s 10500 na jedva 2000. Pored Mezölaborcza, 2. pješačka divizija, dio X. korpusa, počela je bitku s 8150 ljudi, ali je sada ostavljena da drži crtu bojišnice koja je prolazila šumovitim planinama dužine 5 kilometara sa samo 1000 preživjelih." 58

Iako se Buttar slaže s navedenim ocjenama Conradova karaktera (Tominac i djelomično Bassett prikazuju ga kao nerazumnoga zapovjednika, a Watson ga čak i ismijava), nastojao je na neki način opravdati njegove odluke pokušavajući se staviti u njegov kut gledanja, ističući i njegovu "ljudsku stranu". Tako navodi pismo koje je Conrad napisao svojoj ljubavnici na vrhuncu borbi u Karpatima krajem siječnja 1915., iz kojega se može iščitati unutarnje kajanje i osjećaj odgovornosti zbog slanja tolikih ljudi u borbu: "Oskudica u kojoj se nalaze trupe sigurno je neopisivo teška, ali ja bih radije tisuću puta izdržao to nego umni rad i slom živaca u visokoj komandi." ${ }^{59}$

55 Isto, 40.

56 Svetozar Borojević (1856. - 1920.), feldmaršal austrougarske vojske. Od siječnja do kraja svibnja 1915. zapovjednik 3. austrougarske armije na Istočnom bojištu. Opširnije o njemu u: Feldmaršal Svetozar barun Borojević od Bojne (1856. - 1920.). Zbornik radova (Zagreb: Hrvatski institut za povijest, 2011).

57 Prva karpatska ofenziva bila je ofenzivna akcija austrougarske i njemačke vojske koja se odvijala od 23. siječnja do 26. veljače 1915. na području karpatskih prijevoja. Sudjelovale su austrougarska 3. armija pod zapovjedništvom generala Borojevića, Armijska grupa PflanzerBaltin i njemačka Južna armija pod zapovjedništvom generala Linsingena, koje su se borile protiv 8. ruske armije pod zapovjedništvom generala Brusilova. Ciljevi napada generala Conrada bili su sljedeći: austrougarska 3. armija trebala je izravno nastupati prema blokiranoj utvrdi Przemyśl, njemačka Južna armija prema rijeci Stryj, a potom nastaviti bočno prodirati prema Przemyślu, te austrougarska Armijska grupa Pflanzer-Baltin prema gradovima Stanislavu (Ivano-Frankivsk) i Černjivcima kao potpora glavnom napadu 3. i Južne armije.

58 BUTTAR, Germany Ascendant, 76.

59 Isto, 77. 
Kada se uzme u obzir Conradovo zanemarivanje važnosti artiljerije i preciznoga topničkoga gađanja radi probijanja neprijateljskih linija na određenim dijelovima bojišnice kao borbene taktike, autor zaključuje: "Falkenhayn je opetovano tjerao Conrada da napusti operaciju u Karpatima u korist obnovljene kampanje protiv Srbije, ali je načelnik glavnoga stožera austrougarske vojske slijepo slijedio svoje planove. Kontinuirani napadi bili su temeljeni na potpuno nerealističnim očekivanjima da će se ostvariti brzi proboj, a kada je postalo jasno da takav proboj nije moguć, trupe su bačene u borbu uz potpuno zanemarivanje stvarnosti i teškoća brdskih operacija na takvu terenu. Cijeli svoj profesionalni život Conrad je bio vjerni zagovaratelj ofenzivnih operacija koje su trebale biti poduzete po svaku cijenu; njegove su armije platile veliku cijenu uzalud pokušavajući pretvoriti njegovu retoriku u stvarnost." ${ }^{00}$

Drugi razlog slabijeg uspjeha austrougarskih snaga, smatra Buttar, ogleda se u činjenici da su se austrougarske armije borile protiv "najagresivnijega zapovjednika” u cijeloj ruskoj vojsci, generala Brusilova, za koga drži da “je bio najbolji vojni zapovjednik svojega doba". ${ }^{61} \mathrm{U}$ okolnostima kada bi neki drugi ruski zapovjednici gotovo sigurno kapitulirali, što se i dogodilo nekoliko puta na Istočnom bojištu 1915., autor ističe da je Brusilov nevjerojatnom improvizacijom, izrazito agresivnim pristupom i inovativnom borbenom taktikom (grupiranje manjih “jurišnih trupa” za udar na neprijateljske položaje po najslabijim točkama prve crte) uvelike zaslužan za spas mnogih ruskih jedinica od potpunoga poraza tijekom ljeta i jeseni 1915. godine. Ujedno autor ističe "da su austrougarske jedinice [a time i hrvatske, op.a.] imale nesreću da se moraju boriti upravo protiv takva zapovjednika, i to još na tako nepovoljnom terenu". ${ }^{2}$

Zvonimir Freivogel u svojoj je knjizi o tom pitanju zauzeo otprije ustaljen stav hrvatske historiografije o podređenosti austrougarske vojske njemačkoj i ruskoj na Istočnom bojištu 1915., prije svega zbog "diletantskih zapovjednika" koji su vodili jedinice na terenu i pomanjkanja razine borbene spremnosti kakva je bila karakteristična za njemačku vojsku. Propustio je i preciznije iznijeti razloge austrougarskih neuspjeha (Buttar, recimo, ističe nekoordiniranost istovremenih napada i nesuradnju jedinica različitoga etničkog podrijetla). Ne bavi se detaljno svakom pojedinom bitkom niti ulazi u komparativnu analizu tehničkih karakteristika pojedinih vrsta oružja austrougarske, njemačke i ruske vojske, pa je nejasno na čemu zapravo, makar i s tehničkoga aspekta, ne uzimajući u obzir i ostale, temelji svoj stav.

Na primjeru austrougarske artiljerije (za koju Bassett drži da je bila najbolja u ratu) Freivogel je propustio analizirati učinak faktora istreniranosti posada koje su rukovale tim oružjem kao i naznačiti njezinu komparativnu prednost nad njemačkim i ruskim naoružanjem istoga tipa, da bi upravo takvim prikazom dokazao dio cjelokupne uzročno-posljedične veze tijeka $\mathrm{i}$ is-

\footnotetext{
${ }^{60}$ Isto, 156.

${ }^{61}$ Isto, 178.

${ }^{62}$ Isto, 77.
} 
hoda pojedinih ratnih operacija. On samo prikazuje tehničke karakteristike oružja od trenutka njegova ulaska u vojnu upotrebu pa nadalje tijekom rata, kada su uslijedile poboljšane inačice toga oružja, primjerice: "Početkom rata dovršen je razvoj poljskih haubica M 14 kalibra $15 \mathrm{~cm}(149 \mathrm{~mm})$, težine 2765 $\mathrm{kg}$ i dometa do $8000 \mathrm{~m}$, ali još nije počela njihova serijska proizvodnja. Tijekom rata je slijedila i poboljšana inačica $M 14 / 16$ s još većim dometom, kao i teški (odnosno srednji) poljski top M 15 kalibra $10 \mathrm{~cm}$, a zatim još teža topnička oružja, koja su od samog početka bila predviđena za vuču motornim vozilima i nazvana su ' $15 \mathrm{~cm}$-Autohaubitze M 15' (stvarnog kalibra 149,1 mm) i ' $15 \mathrm{~cm}$-Autokanone M 15' (stvarnog kalibra 152, mm). Potonji je imao domet do $20,7 \mathrm{~km}$, što je bilo skoro dva i pol puta više od prethodnika, topova M 80 s dometom do $8 \mathrm{~km} .{ }^{63}$

Taj je podatak zanimljiv sam po sebi, međutim pruža malo praktične koristi ako se ne stavi u pravi vremensko-prostorni kontekst: Freivogel nije naznačio kada su se takvi topovi koristili, protiv kojega neprijatelja, na kojoj konkretno lokaciji, u kolikom broju itd. Jedini primjer kontekstuiranja tehničkih specifikacija nekoga oružja autor donosi u opisu čuvenoga austrougarskoga opsadnog topa - obalnoga mužara M 11 kalibra $305 \mathrm{~mm}$ : "Bila je riječ o oružju težine 20,9 tona, s cijevi duljine 3 metra, koje je ispaljivalo granatu mase 380 $\mathrm{kg}$ na udaljenosti od 5 do 9,6 km. Moglo se za šest sati rastaviti na tri dijela (cijev, postolje i podlogu) i prevoziti posebnim elektromotornim vozilima koje je projektirao Ferdinand Porsche zajedno s dopukovnikom von Preganauom... Prijevoz je bio moguć i željeznicom, a tijekom rata su izrađeni poboljšani tipovi istog mužara (M 11/16, i M 16), kao i nove opsadne haubice M 16 i M 17 kalibra $380 \mathrm{~mm}$. Cijev oružja bila je zajedno s transportnom prikolicom teška 38 tona, prikolica s postoljem (lafetom) je težila 33 tone, a dvije prikolice s podlogom 36,6 i 37,6 tona. Domet granate težine $740 \mathrm{~kg}$ (ili šrapnela težine $600 \mathrm{~kg}$ ), iznosio je kod uporabe čahura s najviše $47,5 \mathrm{~kg}$ barutnog punjenja od 3,6 do $15 \mathrm{~km}$. Naručeno je 14 haubica i dvoje doknadne cijevi, a jedna je postavljena i na oklopnjaču Budapest umjesto prednje kule, ali rezultati pokusa nisu zadovoljavali i ponovo je skinuta." 64

To je oružje uspješno koristila njemačka vojska na Zapadnom bojištu u kolovozu 1914. pri opsadi belgijskih tvrđava Liège i Namur, a poslije je prebačeno na Istočno bojište, gdje ga je austrougarska vojska upotrijebila protiv Rusa. Međutim, kako je vidljivo, autor nije naveo točan raspored tih topova po određenim sektorima bojišnice niti način na koji su upotrebljavani u pojedinim bitkama. Kako je izostala i analiza osposobljenosti austrougarskih topničkih posada, preciznosti gađanja i sl., ostaje pri ovoj samo deklaratornoj konstataciji, bez konkretnoga korisnog podatka kojim bi se prava vrijednost takva naoružanja mogla shvatiti na nekom primjeru, recimo da je napisao da bi veći broj tih topova svakako promijenio odnos snaga i pomogao Borojeviću prilikom "Zimske bitke za Karpate" od siječnja do kraja travnja 1915. godine.

\footnotetext{
${ }^{63}$ FREIVOGEL, Austrougarska vojska, 101.

${ }^{64}$ Isto.
} 
Freivogel se dotaknuo toga pitanja u vrlo malom dijelu jednoga poglavlja svoje knjige (18. poglavlje, "Djelovanja na istočnim bojišnicama od ljeta do zime 1915., str. 206 - 208), gdje uopće ne spominje “Zimsku bitku za Karpate”, nego izlaganje počinje površnim i nepovezanim podacima iz ofenzive Gorlice-Tarnów, a završava ishodom "Crno-žute ofenzive” u Ukrajini. Da je autor zauzeo otprije ustaljen stav najbolje se ogleda u ovom primjeru: "Diletantski' austrougarski zapovjednici napadali su previše 'frontalno' uz velike gubitke, umjesto da pokušaju zaobići protivnika. Rusi su se konačno uspjeli reorganizirati i prijeći u protunapad na vojnu skupinu nadvojvode Ferdinanda i probiti c. i k. položaje kod Stubiela. Ruski napad najjače je pogodio 4. armiju, stanje je bilo poput onoga u Srbiji 1914. i dio postrojbi predviđen protiv Italije također je poslan u Rusiju. Umjesto pobjede na ruskoj jugozapadnoj bojišnici, osvajanja Kowna i prekida ruskih 'rošada' kroz Pripjatske močvare, Austrijanci su poraženi i izgubili 230,000 ljudi. Od 109,000 nestalih, čak se 100,000 predalo Rusima! U njemačkim postrojbama je među časnicima bilo oko 5,2 posto nestalih i zarobljenih, kod austrougarskih skoro 30 posto, a kod 4. vojske čak 33 posto. Broj i postotak zarobljenih bio je među vojnicima dvostruko veći, tako je 4. vojska imala skoro 62 posto nestalih, od kojih se većina predala. Cijele postrojbe su se jednostavno 'izgubile’, među njima 19. pješačka pukovnija (sastavljena od Čeha i Rutena), 22. bojna poljskih lovaca (Feldjäger) iz češkoga Egera i 1. bosansko-hercegovačka pukovnija." ${ }^{65}$

Tominac je pak zauzeo pozitivan stav o borbenoj spremnosti austrougarske vojske. On zapravo u svojoj analizi ne propituje borbenu spremnost pojedinih jedinica, nego svrhovitost cjelokupne austrougarske strategije iz perspektive zapovjednika i časnika na terenu, koji su bili u neposrednoj blizini područja na kojem su morali izvesti napad (Tominac iz perspektive Borojevića, Buttar iz Brusilovljeve). Ta se strategija temeljila na oslobađanju opkoljene tvrđave Przemyśl radi odbacivanja Rusa s teritorija Austro-Ugarske. ${ }^{66} \mathrm{~S}$ tim u vezi kaže sljedeće: "Ovakvi Conradovi stavovi zabrinuli su niže zapovjednike, osobito generale Borojevića i Pflanzer-Baltina koji su - poznavajući mogućnosti svojih snaga - sumnjali u uspjeh operacije. Nesigurni sustavi veza, nemogućnost manevra velikih snaga, poglavito artiljerije, logistička nepripremljenost vojnika za zimske i planinske uvjete ratovanja bili su u nesrazmjeru s očekivanjima. Conrad je odbio odgoditi napad, i austro-ugarska vojska će se osim protivničkih morati boriti i protiv prirodnih nepogoda." ${ }^{67} \mathrm{U}$ tijeku pojedinih operacija Tominac propituje i opravdanost žrtvovanja tolikoga broja ljudi u "bijelom paklu" radi postizanja vrlo malenoga učinka sa stajališta vojne logike - postizanja taktičke prednosti, pa se u prilog tome može izdvojiti njegova tvrdnja: "Borbe

65 Isto, 207.

${ }^{66}$ Bassett smatra da je ta strategija u zimskim mjesecima bila potpuno pogrešna jer Przemyśl 1915. više nije imao nikakvo strateško značenje: "Iako neprestano moderniziran, napredak opsadne tehnologije bio je toliko brz da do 1914. Przemyśl nije više smatran modernim, iako je pokazao da su njegove zastarjele obrambene strukture bile sposobne izdržati napad." BASSETT, For God and Kaiser, 476.

67 TOMINAC, “Ličani u 'Velikom ratu”, 499. 
su proizvele šest puta više žrtava u odnosu na broj vojnika pod opsadom u tvrđavi Przemysl, koja je bila jedan od glavnih ciljeva ove sulude vojne operacije. Gubitci na obje strane nadmašuju one na Zapadnom bojištu koji su se dogodili u bitkama kod Verduna i na Sommi. Računa se da je oko milijun vojnika obje zaraćene strane svojom krvlju natopilo snjegove Karpata." ${ }^{8} \mathrm{U}$ tom pogledu, njegovi su stavovi slični Buttarovima. Metodološki oba autora rekapitulacijom gubitaka na kraju svakoga tematskog poglavlja zapravo naglašavaju golem nerazmjer između strateško-taktičke prednosti postignute pojedinim ratnim operacijama i nenadoknadivih ljudskih gubitaka koji su u konačnici doveli do brojnih problema Austro-Ugarske Monarhije i sloma Rusije. Tominac o tome zaključuje riječima: "Bitka je zasigurno utjecala na ubrzanu gospodarsku i političku propast Rusije, osobito nakon austro-njemačkog proboja kod Gorlica i Tarnowa iz svibnja 1915. godine."69

Kako je Tominac pukovnik Hrvatske vojske, moglo bi mu se prigovoriti da pretjerano naglašava važnost borbi na Istočnom bojištu 1915. govoreći o brojnim užasnim uvjetima, nadljudskim naporima i neviđenim patnjama $\mathrm{u}$ kojima su zaraćene vojske ratovale ${ }^{70}$, kao i da je pristran, jer se ipak radi o borbama u kojima su sudjelovali hrvatski vojnici. Međutim, kada se ti podaci usporede s podacima u radovima drugih autora (Buttar i Watson) te uvidom $\mathrm{u}$ isto ili komplementarno arhivsko gradivo koje su svi ti autori koristili, ne može mu se pripisati namjera pretencioznoga naglašavanja uloge, doprinosa i na kraju žrtve hrvatskih vojnika u spomenutim događajima. Prvenstveno je Tominac imao cilj prikazati ratne strahote "običnog hrvatskog vojnika" ${ }^{71} \mathrm{i}$ intenzitet borbi, koji su u mnogočemu nadilazili uvjete s ostalih bojišnica, $s$ kojima je hrvatska javnost bolje upoznata, a hrvatska historiografija posvetila im je više interesa nego upravo tim događajima za koje je autor iznio obilje podataka. Važan doprinos hrvatskoj historiografiji Prvoga svjetskog rata autor je dao u prilozima kada navodi imena i prezimena u Popisu stradalih hrvatskih vojnika $^{72}$ u toj "Staljingradskoj bitci Prvog svjetskog rata".73

\footnotetext{
${ }^{68}$ Isto, 492.

69 Isto.

${ }^{70}$ "Iz izvještaja 34. pješačke divizije/XIX korpusa saznajemo da 'po cestama leže iscrpljeni vojnici pogođeni hladnoćom, zatrpani snijegom i neprohodnim terenom. Takvo stanje doseglo je široke i masovne razmjere. U izvještajima 17. pješačke divizije/VII. korpusa stoji da u jednoj satniji 'trideset ljudi boluje od promrznutih nogu, u druge dvije satnije devedeset šest je slučajeva pojave smrzotina." Isto, 503.

71 "Zbog vrlo niskih temperatura brojni smrznuti vojnici ostali su ležati po okolnom prostoru. Mnogi oboljeli od smrzavanja šalju se kućama na liječenje jer su bolnice bile pretrpane. Od ozeblina često je nastupala gangrena zbog koje su ozlijeđenima otpadali obamrli dijelovi tijela, tako da su bili izloženi višednevnim patnjama dok na kraju ne bi umrli. Pojedine obitelji još se uvijek sjećaju tih tragičnih događaja svojih predaka. Prema osobnom kazivanju Steve Maoduša iz Zagreba zabilježen je slučaj o patnjama njegovog djeda Stevana koji je neposredno nakon povratka s Karpatskog ratišta umro od gangrene u selu Medak kod Gospića." Isto, 504.

${ }^{72}$ Isto, 519-523.

${ }^{73}$ Isto, 503, navodeći Tunstalla.
} 
Dominic Lieven obrađuje to pitanje s druge točke gledišta: iz ruske perspektive. On zastupa tezu da ruska vojska nije bila nimalo inferiorna njemačkoj, ali da je bila mnogo bolja od austrougarske vojske. Čak smatra da je ruska vojska mogla poraziti austrougarsku, a poslije, uz pomoć svojih zapadnih saveznika, i njemačku vojsku na Istočnom bojištu 1915. godine. Svoju tezu brani ovako: "Ruski Prvi svjetski rat tekao je uglavnom onako kako ga je najinteligentniji 'reakcionarni' vođa Rusije Petar Durnovo predvidio u svojem Memorandumu iz veljače 1914. godine. Ruska vojska bila je inferiorna njemačkoj te je bila poražena u brojnim bitkama, najviše kod Tannenberga 1914. i GorlicaTarnówa 1915. godine. Na brojnim područjima njemačka superiornost u materijalu bila je važna; najistaknutije u teškoj artiljeriji, zrakoplovima i komunikacijskoj tehnologiji. Dublje ukorijenjeni problemi ruskoga osoblja značili su više. Relativno malen broj profesionalnih i zamjenskih časnika u usporedbi s Njemačkom pokazao se kao veliki nedostatak. Ruske armije obično su imale manje kompetentne zapovjednike i osoblje nego njihovi njemački neprijatelji. Ali britanska i francuska vojska u cjelini bile su inferiorne njemačkoj, sve dok posljednja nije osakaćena Ludendorffovom proljetnom ofenzivom 1918. godine. U pojedinim prilikama ruske armije porazile su njemačke. Općenito su bile superiorne u odnosu na austrijske armije, koje su teško porazile 1914. i 1916. godine. Ruska vojska također je nadmašila u izvedbi britansku vojsku u ratu protiv Turske." 74

Prema Lievenovu mišljenju, rusku su vojsku u postizanju ratne pobjede onemogućavala tri faktora. Prvi je gubitak velikoga broja profesionalnih časnika: "Do veljače 1917. stara je vojska nestala: većina redovnih časnika, neslužbujućih časnika i mirnodopskih vojnika koji su otišli u rat 1914. bila je izgubljena u ubojitim kampanjama sljedećih 20 mjeseci." ${ }^{75}$ No gubitak profesionalnih časnika nije bio samo ruski problem; austrougarska vojska bila je najviše pogođena gubitkom profesionalnoga časničkoga kadra, a u njemačkoj je vojsci taj problem bio mnogo više izražen na Zapadnom bojištu u istom razdoblju. ${ }^{76}$

74 LIEVEN, Towards the Flame, 343.

75 Isto, 352. Buttar još detaljnije analizira taj problem navodeći zapis velikoga vojvode Nikolaja, vrhovnoga zapovjednika ruske vojske od izbijanja rata do kolovoza 1915., iz srpnja 1915. godine: "U sažetku koji je poslao caru veliki vojvoda Nikolaj žalio se na jadnu kvalitetu zamjenskih novaka: 'Oni su ništa više nego jedva izvježbani seljaci, koji u nedostatku pušaka jedva da i znaju pucati."' BUTTAR, Germany Ascendant, 275.

76 Problemom gubitka profesionalnoga časničkoga kadra koji je uzrokovao smanjenje borbene spremnosti jedinica u austrougarskoj i njemačkoj vojsci detaljnije se bavi Watson. Primjerice, za austrougarsku vojsku na jednom mjestu kaže: "Za razliku od predratnih profesionalaca poliglota, rezervni su časnici često govorili samo jedan jezik. Velika razlika između etničkoga podrijetla rezervnih časnika i običnih vojnika značila je da su se mnogi od njih našli na čelu jedinica s kojima su jedva mogli komunicirati, a kamoli djelovati. Korpusi su postali mnogo manje homogeni i ujedinjeni. Gdje su časnici bojne bili miješanoga etniciteta, moglo je biti napetosti." WATSON, Ring of Steel, 286-297. O tome načelno govori i Bassett, naslovivši 24. poglavlje svoje knjige For God and Kaiser "1916. - 1918. Kraj stare vojske” (str. 498 - 510). 
Drugi faktor, smatra Lieven za razliku od do sada ustaljenoga historiografskog stava o ruskoj ulozi i položaju na Istočnom bojištu tijekom 1915., nije ležao u ekonomskoj zaostalosti Rusije i problemima domaće proizvodnje, nego u pogrešno konstruiranoj i loše vođenoj i održavanoj željezničkoj mreži i prometu. Tu tezu obrazlaže riječima: "U nekim pogledima ruska ekonomija radila je začuđujuće dobro do 1916. godine. Osnovna proizvodnja oružja i streljiva zadovoljena je iz domaćih izvora. Nove strateške industrije stvorene su od otpada da bi se nadoknadio izgubljeni uvoz. Ali u nekim vojnim područjima, iznad svega pogonskim strojevima i motorima svih vrsta, Rusija je znatno zaostajala za Njemačkom." ${ }^{77}$

Poput drugih britanskih autora u ovom radu, Lieven je analizirao problem opskrbe vojske streljivom i hranom, ali s drukčijega stajališta. On naime drži da problem nije bio u zaostalosti ruskoga željezničkog i prometnog sustava, nego u određivanju prioriteta i distribuciji: "Čak i 1917. Rusija je još uvijek proizvodila dovoljno hrane da hrani samu sebe: poteškoća je bila dostaviti ju razmaženoj populaciji gradova ruskih sjevernih industrijskih regija i golemoj vojsci koncentriranoj u zapadnim carskim pograničnim područjima. Željeznička je mreža u mirnodopsko vrijeme bila usmjeravana da prevozi viškove žita iz južne Ukrajine i ruskih južnih stepskih regija ne sjeverno, nego u južne ispostave na Crnom moru. Jednako važni bili su sukobi vojske, brojnih civilnih ministara i lokalnih vladinih tijela (zemstva) oko cijene i nabavke žita. Veliki posjedi koji su sve svoje žito slali na tržište bili su jako pogođeni nedostatkom radne snage kada je 15 milijuna ljudi bilo pozvano u oružane snage. U međuvremenu, industrija nije mogla opskrbljivati vojsku i proizvoditi dobra za konzumiranje istovremeno po cijeni i u količini koje bi mogle uvjeriti seljake da prodaju svoje žito." 78

Kao treći i najvažniji faktor Lieven spominje nedostatak političkoga konsenzusa između cara Nikole II., vojnoga zapovjedništva, vlade i ministarstava i ruske skupštine Dume: "Najbliže pojmu ratnoga heroja i javne ikone što je Rusija imala bio je veliki vojvoda Nikolaj, koji je postao vrhovnim zapovjednikom armija na Istočnom bojištu 1914. godine. Njegov izgled bio je impozantan, a reputacija najvećega nacionalista i antinijemca od svih Romanova također je pridonijela njegovu ugledu. Iz vladine perspektive, tri su velika problema s velikim vojvodom bila očita do ljeta 1915. godine. Prvo, svrstao se uz političare iz Dume u pritisku na Nikolu II. da smijeni konzervativne ministre i davanju ustupaka javnom mišljenju. Drugo, pod vodstvom velikoga vojvode, glavni stožer vojske postao je carstvo za sebe, ignorirajući molbe ministara i prilagođavajući politike na golemim područjima iza bojišnice koja su sami kontrolirali, prilikom remećenja civilne ekonomije i društva. Najekstremniji primjer bila je politika vojske u prisili većine civilnoga stanovništva da napusti svoje domove i preseli se u unutrašnjost tijekom velikoga povlačenja u proljeće i ljeto 1915. godine. Ta je politika praćena mnogim zločinima protiv neruskoga

\footnotetext{
77 LIEVEN, Towards the Flame, 345.

78 Isto.
} 
stanovništva, pogotovo Židova. Treće i najvažnije, veliki vojvoda bio je slab general, isto tako sklon panici i očajavanju kako je ruska vojska posrtala pred austro-njemačkim ofenzivama 1915. godine." ${ }^{\text {99 }}$

No u odluci cara Nikole II. da smijeni Nikolaja Lieven vidi glavni uzrok nadolazeće ruske katastrofe, pa zaključuje da je upravo car u očima javnosti i vojske (ali i revolucionara 1917.) bio glavna prepreka ruskoj pobjedi u ratu: "Pod udarom ozbiljnih vojnih poraza koji su uslijedili nakon njemačkoga proboja kod Gorlica-Tarnówa, većina stranaka u Dumi formirala je tzv. Progresivni blok i pozvala Nikolu da postavi vladu prihvatljivu ruskom društvu, za koje je blok tvrdio da ga predstavlja... Car je odbio. U ljeto 1915. već je napravio niz bitnih ustupaka Dumi i javnosti, uključujući otpuštanje ključnih konzervativnih ministara. Daljnje ustupke vidio je kao pritisak i slabost i kao de facto ustupak parlamentarnoj vladi koja je, prema njegovu mišljenju, vodila prema raspadu autoriteta, a potom socijalnoj i narodnoj revoluciji... Odbijajući taj kompromis, Nikola se našao sve više izoliran, snoseći sam odgovornost za sve neizbježne ratne probleme i odbačen čak i od mnogih njegovih sposobnih i iskusnih vojnih i civilnih dužnosnika. Kada je revolucija izbila na ulicama Petrograda u veljači 1917., elite Rusije izgubile su povjerenje u Nikolu i napustile ga." 80

Lieven dakle nije analizirao pitanje sposobnosti vojske da pobijedi u ratu, nego smatra ruskoga cara osobno najvećim krivcem što je pogrešno vodio zemlju u ratu. Svoju tezu obrazlaže time što uzima u obzir činjenicu da je car Nikola II. osobno preuzeo vrhovno zapovjedništvo nad vojskom u kasnom kolovozu 1915., pretpostavljajući time u najvećoj mjeri njegovu odgovornost za vojne operacije na Istočnom bojištu od toga trenutka nadalje.

David Stevenson nije se izravno bavio tim pitanjem, ali je dao pojedine navode iz kojih bi se mogao izvesti zaključak u pogledu odnosa snaga zaraćenih vojski na Istočnom bojištu, primjerice: "U realnim iznosima, Austro-Ugarska je manje potrošila na rat 1917. i 1918. nego 1914. i 1915. godine." ${ }^{81}$ Moglo bi se zaključiti da se Stevenson slaže s Watsonom i Buttarom u pogledu daljnje sposobnosti Austro-Ugarske Monarhije da uspješno nastavi rat zbog sve veće ovisnosti o Njemačkoj, no ostaje činjenica da dalje u tekstu sam autor nigdje izrijekom ne spominje tako formuliranu tezu.

Mogao bi se istaknuti prigovor toj tvrdnji da je doista nejasno "o kojim se to realnim iznosima radi". Takva formulacija ne nudi egzaktan i precizan uvid u "ratni napor", odnosno strukturu financijskoga troška Austro-Ugarske Monarhije 1915. kako to primjerice čini Watson, što je u neku ruku i razumljivo jer se tematski ograničio na prikaz Njemačke i Austro-Ugarske u Prvom svjetskom ratu, a Stevenson je obrađivao sve zaraćene države, stoga se detaljnijom analizom pojedinih razdoblja pojedine zaraćene strane jednostavno nije bavio.

\footnotetext{
79 Isto, 347.

80 Isto, 349.

${ }^{81}$ STEVENSON, 1914. - 1918., 548.
} 
Uspoređujući taj podatak s podatkom u Čitanci-priručniku prema tablici 2 "Svi ratni dugovi Monarhije u američkim dolarima" ${ }^{82}$, u kojoj je detaljnom analizom prikazana struktura financijskoga troška Austro-Ugarske Monarhije u Prvom svjetskom ratu, dobiva se potpuno suprotna slika. Tablica je podijeljena prema načinu posudbe novca za austrijski i ugarski dio Monarhije, s preciznim prikazom prema pojedinim ratnim godinama. Tako se za 1915. navodi dug od 2.808.000.000 američkih dolara za austrijski, a 1.962.514.000 za ugarski dio Monarhije. U odnosu na 1914., kada je taj iznos bio 1.008.000.000 za austrijski, a 1.339.114.000 za ugarski dio, evidentan je i logičan porast potrošnje zbog izbijanja rata. Štoviše, u odnosu na 1916., on iznosi 6.277.800.000 američkih dolara za austrijski i 3.276.042.000 američkih dolara za ugarski dio. Očito povećanje duga podrazumijeva i povećanje potrošnje. Pritom je potpuno irelevantno radi li se o financiranju industrijske, ratne proizvodnje ili potrošnje stanovništva (što nije bio slučaj, jer se u nekoliko prilika iznosi činjenica "pada životnoga standarda" ${ }^{33}$ ).

S druge strane, upravo se Alexander Watson u knjizi Ring of Steel jasno odredio o tom pitanju. Premda je njegova analiza cjelokupna, s različitih aspekata i obiljem novih i korisnih podataka, autor u pogledu ocjene borbene spremnosti austrougarske vojske nije napravio odmak od prethodno ustaljenih historiografskih obrazaca te donio originalne zaključke poput Bassetta, Buttara ili Tominca. Poglavlja njegove knjige indikativnih naslova (3. poglavlje "Rat iluzija", str. 104 - 160) jasno pokazuju da autor smatra da su austrougarske oružane snage u cjelini bile inferiorne Antantinima, a pogotovo ruskima.

Poput Lievena, Watson drži da je nedostatak političkoga konsenzusa umanjivao borbenu spremu austrougarske vojske. Smatra da se vojska nije toliko loše borila koliko je političko i vojno vodstvo podbacilo u svojoj (propagandnoj ili patriotskoj) zadaći mobiliziranja "srdaca i umova" mnogih nacija Carstva. Dok je u Njemačkoj koncept Burgfrieden ${ }^{84}$ ostvario znatan uspjeh, u Austro-Ugarskoj Monarhiji takav je pokret kao dio ratne kulture izostao:

\footnotetext{
${ }^{82}$ DESPOT et al., Prvi svjetski rat, 55.

83 “Životni standard u Beču pao je drastično u odnosu na Pariz i London i počeo je nalikovati očajnim uvjetima u Petrogradu. Prihodi grada su 1916.-1917. pali na 64 posto u odnosu na 1913.-1914., a 1917.-1918. na 37 posto. Do 1914. je austrijska polovica uvozila 32 posto svoje potrošnje žitarica (65 posto tog uvoza dolazilo je iz Mađarske), ali 1917. austrijska žetva pala je na 40 posto u odnosu na predratnu, a uvoz iz Mađarske iznosio je samo 2,4 posto. Industrijska proizvodnja bila je 1917. u strmom padu, loše održavane željeznice počele su zastajkivati, a opskrba ugljenom svela se na 40 posto predratne količine. Visoke peći su zatvarane, pa je i proizvodnja oružja patila. Između ožujka i kolovoza proizvodnja granata pala je s 50.000 na 18.000 dnevno, a proizvodnja streljiva za mitraljeze smanjila se za tri četvrtine." STEVENSON, 1914. - 1918., 507.

${ }^{84}$ Burgfrieden je bio njemački pojam za političko primirje među najvažnijim političkim strankama u Njemačkoj tijekom Prvoga svjetskog rata. Sastojao se u tome da stranke nisu kritizirale vladu, izglasavale su potrebne ratne kredite i podupirale cjelokupni ratni napor, a sindikati i radnici obvezali su se suzdržati od štrajkova. Na osobnoj razini, Burgfrieden je označavao štednju, solidarnost i skupljanje hrane i tople civilne odjeće koja se slala vojnicima na bojišnici. Osnovne vrijednosti toga koncepta su jedinstvo i žrtva. Burgfrieden je bio samo jedan od sastavnih elemenata tzv. ratne kulture.
} 
"Habsburško Carstvo nikada nije postiglo njemačko jedinstvo svrhe ili jednosmjernu mržnju jednoga neprijatelja." Autor smatra i da je mržnja njemačke javnosti uspješno usmjerena prema jednom jedinom neprijatelju (Engleska), a "podanici Franje Josipa vodili su nekoliko lokalnih ratova, a ne jedan veliki imperijalni rat". ${ }^{85}$ Nadalje autor izlaže sve političke probleme Dvojne Monarhije, koji su u prepiranjima i sukobima oko nadležnosti i odgovornosti za pojedina pitanja obilježili odnose austrijskoga i mađarskoga dijela Monarhije u daljnjem tijeku rata. S tim u vezi samo načelno kaže da su "od siječnja 1915. Mađari ograničili svoj izvoz u Austriju”", pa zaključuje da je "neuspjeh Habsburškoga Carstva da osigura narativ imperijalnoga rata naširoko naštetio predanosti i jedinstvu njegovih naroda, kao i snazi i svrsi njihova ratnoga napora". ${ }^{87}$

Iz pregleda različitih pogleda pojedinih britanskih i hrvatskih autora na to pitanje vidljivo je da postoje vrlo različita mišljenja i historiografske ocjene. Neki su nastojali (poput Bassetta, Buttara i Tominca) snagom svoje narativne uvjerljivosti, navodeći primarne izvore, dokazati svoje hipoteze. Drugi pak, poput Stevensona, Lievena i Watsona, kao da su analizirali borbena djelovanja post festum, u kontekstu cijeloga trajanja Prvoga svjetskog rata. No ostaje činjenica da se austrougarska vojska nije „raspala” nakon početnih poraza i velikih gubitaka tijekom jeseni i zime 1914., pa čak ni nakon neuspjele (sa strategijskoga aspekta) ofenzive u "Zimskoj bitci za Karpate" i gubitka 800 tisuća vojnika. Štoviše, nije se raspala ni na završetku borbenih operacija na Istočnom bojištu 1915., kada Buttar navodi da je imala 1,8 milijuna ljudskih gubitaka. S tim u vezi, mislim da je bez obzira na spomenute mane i nedostatke Carska i kraljevska vojska bila itekako opasan protivnik i važna vojna sila.

\section{Je li Prvi svjetski rat mogao završiti već 1915. kao posljedica događaja na Istočnom bojištu?}

Većina britanskih autora u svojim radovima nije odoljela spekulativnoj znatiželji da ne postavi, izravno ili neizravno, ovo pitanje. Pristup hrvatskih autora bitno je drukčiji. Freivogel se usredotočio na prikaz tehničkih karakteristika pojedinih vrsta naoružanja austrougarske vojske, a o ovom se pitanju nije izravno i izričito izjasnio, nego se ograničio na iskazivanje stava koji potvrđuje prije formiranu ocjenu (ne)kompetentnosti austrougarskoga vojnog vodstva, što je rezultiralo porazom na Istočnom bojištu na kraju 1915. godine.

85 WATSON, Ring of Steel, 242.

${ }^{86}$ Isto, 244. Ovdje su Bassett i Buttar malo detaljniji, pa prvi kaže: "Mađarska se vlada 1914. obvezala isporučivati 30 tisuća svinja godišnje Austriji. Do 1916. taj se broj smanjio na manje od 8000." BASSETT, For God and Kaiser, 511. Drugi donosi ovaj podatak: “Mađarski premijer István Tisza žalio se u rujnu 1915. da Mađarska čini nešto manje od $41 \%$ ukupne populacije Carstva, a opskrbljuje vojsku s 43,5 \% ljudstva, stoga bi Austrija odmah trebala povećati svoj udio tereta. Odgovor je glasio da je austrijski teritorij uključivao dijelove Galicije, koju su okupirali Rusi, pa ne može doprinijeti ljudstvom, tako da daljnje natezanje oko toga koliki je udio mrtvih iz svake zemlje nije pomoglo da se poboljšaju odnosi." BUTTAR, Germany Ascendant, 392.

87 WATSON, Ring of Steel, 256. 
Herman Kaurić, Paščenko i Tominac bili su više zainteresirani za rasvjetljavanje sudbine jedinica u kojima su služili hrvatski vojnici i časnici te određivanje što je moguće preciznijega broja mrtvih, ranjenih, nestalih ili zarobljenih. Nastojali su odati počast žrtvama rata te postaviti okvir istraživačima za buduće radove u tom smjeru.

U skladu s izloženom pojedinačnom analizom svakoga rada, može se zaključiti sljedeće. Bassett smatra da je rat mogao završiti već 1915., i to kolapsom Rusije, da su elitne alpske postrojbe i fantastična austrijska brdska artiljerija (za koju autor drži da je bila najbolja od svih zaraćenih vojski u ratu te na tom argumentu ističe njezinu komparativnu prednost) bile prisutne prilikom ljetnih ofenziva Centralnih sila na Istočnom bojištu 1915. godine.

Buttar se djelomično slaže s takvim stavom, iako izvodi sasvim suprotan zaključak, koji bi se mogao svesti na jednostavnu formulu: Njemačka je mogla pobijediti i završiti rat 1915., Austro-Ugarska isključivo kao njezin "mlađi partner", nikako samostalno, a Rusija je 1915. izgubila svaku šansu za pobjedu u ratu (što se u konačnici pokazalo točnim). Ovako to iznosi Buttar. Najprije navodi zapis Conrada von Hötzendorfa u kojem načelnik glavnoga stožera prihvaća realnu činjenicu da je pobjeda gotovo nemoguća: “[...] s našim jedinicama ne može se planirati ofenziva. $U$ ovom ratu nikada nismo imali nešto tako jednostavno, tako sigurno kao ovu ofenzivu, a čak smo i to uspjeli zabrljati”s8, nakon poraza austrougarske vojske u "Crno-žutoj ofenzivi". Zatim, u pogledu njemačke vojske: "Štoviše, uspoređujući ju s ostalim velikim silama, njemačka se vojska poboljšala u mnogim pogledima tijekom 1915. godine. Na kraju godine brojno je bila snažnija nego prije te je unatoč gubitku preko milijun vojnika na svim bojištima imala više teške artiljerije i strojnica nego prije. Veći je problem bio što su zahtjevi stavljeni pred vojsku bili veći, pogotovo s obzirom na padajuću moć Austro-Ugarske." ${ }^{89}$ Naposljetku, za rusku vojsku kaže da su "carske armije završile godinu u lošem stanju. Broj iskusnoga i dobro treniranoga osoblja alarmantno je padao, a nedostaci režima treniranja zamjenskih novaka okrutno su se pokazivali kako su se jedinice slale na bojišnicu".90

Zaključak Buttar donosi u posljednjem poglavlju, "Teret rata" (str. 389 405). Posljedice događaja koji su se odigrali na Istočnom bojištu 1915. imale su tri različita učinka za zaraćene strane. Prema njegovu mišljenju, Njemačka je postigla strateški uspjeh $i$, što je važnije, dokazana je superiornost njemačke vojske nad ruskom, pa su njemački vojni zapovjednici zaključili da Rusi ne mogu poraziti Nijemce u daljnjem tijeku ratovanja: od tada nadalje Rusi im ne predstavljaju prijetnju. Zato će se za sljedeću godinu njemačka ratna strategija usredotočiti na Zapadno bojište, pa autor donosi zanimljiv tekst jednoga memoranduma koji je načelnik glavnoga stožera Falkenhayn sastavio za njemačkoga cara Vilima II.: "Francusko naprezanje gotovo je dostiglo točku

\footnotetext{
88 BUTTAR, Germany Ascendant, 351.

${ }^{89}$ Isto, 400.

${ }^{90}$ Isto, 401.
} 
slamanja. Ako uspijemo njezinu narodu otvoriti oči činjenicom da se u vojnom smislu oni nemaju čemu nadati, ta će se točka slamanja dostići i najbolji engleski mač bit će izbijen iz njezine ruke. Da bi se postigao taj cilj, nesigurna metoda masovnoga proboja, u svakom slučaju izvan naših mogućnosti, nije potrebna. Vjerojatno za svoje potrebe možemo učiniti dovoljno s ograničenim resursima. U našem dohvatu iza francuskih sektora Zapadnoga bojišta postoje ciljevi za čije bi zadržavanje francuski glavni stožer bio primoran ubaciti svakoga čovjeka kojega imaju. Ako to učine, snage Francuske nasmrt će iskrvariti - kako nema govora o dobrovoljnom povlačenju - dostigli mi svoj cilj ili ne. Ako to ne učine, a mi dostignemo svoje ciljeve, moralni učinak na Francusku bio bi enorman... Ciljevi o kojima sada govorim su Belfort i Verdun. Prije spomenute opaske odnose se na oboje, iako prednost treba dati Verdunu." ${ }^{\text {91 }}$

U pogledu Rusije autor zaključuje da njezino vodstvo nije izvelo nijedan pravilan zaključak iz ishoda borbi na Istočnom bojištu: "Unutar nekoliko tjedana što je trajao rat Stavka je procijenila da je potrebno 1,5 milijun granata mjesečno, u usporedbi s predratnom procjenom od samo 500 tisuća. Čak se i taj broj pokazao preniskim uz mjesečnu potrebu koja se penjala na preko 3 milijuna granata do sredine $1915 \ldots .$. Na početku godine mjesečna proizvodnja granata u Rusiji bila je 450 tisuća i polako se povećala dok nije prešla jedan milijun u rujnu. To je još uvijek bilo premalo prema potrebama i vodilo je do prezauzetosti nedostatkom streljiva kao najvažnijim faktorom ruskoga poraza... Koncentrirajući se na nedostatak streljiva, Rusi nisu uspjeli shvatiti da postoje i drugi načini da se dostigne njemačka prednost, poput bolje izgradnje terenskih položaja." ${ }^{2}$

Za Austro-Ugarsku Monarhiju drži da je pretrpjela najteže posljedice zbog ratnih zbivanja na Istočnom bojištu 1915. godine. Unutarnje se stanje pogoršalo, a javnost je zapravo od toga trenutka počela negativno gledati na rat. Donosi dva navoda u prilog tome: "Na ulicama Praga pojavili su se natpisi s tekstom: Marširamo protiv Rusa ali ne znamo zašto"93 i: "Mađarski premijer István Tisza žalio se u rujnu 1915. da Mađarska čini nešto manje od 41 \% ukupne populacije Carstva, a opskrbljuje vojsku s 43,5\% ljudstva, stoga bi Austrija odmah trebala povećati svoj udio tereta. Odgovor je glasio da je austrijski teritorij uključivao dijelove Galicije, koju su okupirali Rusi, pa ne može doprinijeti ljudstvom, tako da daljnje natezanje oko toga koliki je udio mrtvih iz svake zemlje nije pomoglo da bi se poboljšali odnosi." ${ }^{\prime 4}$

Potpuno suprotno misli Watson. On zastupa tezu da je Austro-Ugarska Monarhija izgubila rat odmah na početku ratnoga sukoba. Tako indikativno naslovljava 3. poglavlje, "Rat iluzija" (str. 104 - 159), u pogledu njemačkih i austrougarskih ratnih planova na početku rata, kao i jedno potpoglavlje, "Istočne

\footnotetext{
91 Isto, 404.

92 Isto, 395.

93 Isto, 391.

94 Isto, 392.
} 
utopije" (str. 265 - 280), iz čega se može jasno zaključiti da zapravo otklanja mogućnost vojne pobjede austrougarske vojske na Istočnom bojištu.

Svoju tezu obrazlaže ističući da su ruske armije okupirale veći dio Galicije i Bukovine, dviju ekonomski i demografski mnogo važnijih krunskih zemalja Monarhije nego što je to bila Istočna Pruska za Njemačku: "Sjeme kolapsa Habsburškoga Carstva posijano je invazijom. Ekonomski, Galicija je bila, u suprotnosti s napadnutom provincijom Reicha, krucijalna regija. Bila je nezamjenjiva za austrijsku opskrbu hranom, sadržavajući trećinu obradive zemlje zapadnoga dijela Carstva. Invazija je poremetila njezinu poljoprivredu, uništila infrastrukturu i prorijedila stoku. Na istoku krunske zemlje broj konja i krava pao je ispod $40 \%$, a svinja za katastrofalnih $70 \%$. Ta šteta za uzgoj uskoro će se osjetiti po kuhinjama diljem Austrije i bit će ključni uzrok nestašica i gladovanja koje je donijelo socijalni i politički nemir u kasnijim ratnim godinama. Usto je Galicija bila glavni izvor petroleja za Centralne sile. Njezina naftna industrija pretrpjela je znatnu štetu: dvije trećine postrojenja bilo je uništeno, neki su izvori bili zapaljeni i otprilike milijun tona nafte izgubljeno je štetom na spremnicima i zaustavljanjem proizvodnje. No tu su ruske carske armije u povlačenju propustile potencijalnu odlučujuću priliku. Prezaposlene maltretiranjem Židova da bi prepoznale stratešku važnost naftnih polja, nisu izvele nikakvu sustavnu sabotažu i čak su ostavile 480 tisuća tona nafte u spremnicima. Galicija je nastavila osiguravati tri petine ratnoga benzina i dizela Centralnih sila. Zloglasne njemačke podmorničke kampanje poslije u sukobu ne bi bile moguće bez toga." ${ }^{95}$

Posebno ističe negativne posljedice za drugu krunsku zemlju, Bukovinu: “Teritorij koji su Rusi pregazili bio je dragocjen. Gubitak Černjivaca bio je veliki udarac na prestiž, a predaja rudnika Jakobeny u Bukovini, jedinoga carskog izvora mangana, imao je ozbiljne učinke na austrougarski ratni napor. Iako su bosanski rudnici djelomično nadomjestili gubitak, on je primorao AustroUgarsku da smanji postotak mangana u svojem čeliku." ${ }^{96}$

Svoju tezu dodatno obrazlaže iznošenjem negativnih socijalnih, demografskih i u konačnici političkih učinaka kao posljedicu gubitka tih dviju krunskih zemalja: "Preko milijun ljudi napustilo je svoje domove i potražilo zaklon u austrijskoj unutrašnjosti 1914. - 1915. godine. Oni su nametnuli golem financijski teret austrougarskoj državi. Sveukupno je na pomoć prognanicima potrošeno 2.243.100 kruna, što je bilo 2,36 \% austrougarskoga izravnoga ratnog troška." ${ }^{97}$ Osim što je prognanički val uzrokovao razne epidemije ${ }^{98}$, u pogledu tih tragičnih događaja autor potpuno pravilno zaključuje da "invazije Rusije na Njemačku i Austriju ne zauzimaju danas mnogo mjesta u povijesnim knji-

95 WATSON, Ring of Steel, 199.

96 Isto, 327.

${ }^{97}$ Isto, 199. Ako se taj podatak uzme u obzir, tada je Stevensonova tvrdnja o "realnim iznosima” opravdana.

98 "Kako bi skrpali kraj s krajem, prognaničke obitelji natrpale su se u zajedničke sobe, pridonoseći time porastu epidemijskih bolesti tijekom prve polovine 1915. godine.” Isto, 204. 
gama. Žrtve su bile zaboravljene, zanemarena je njihova patnja i zla koja su im učinjena. Premda se važnost ruskih napada ne smije previdjeti... Rasna ideologija, antisemitizam i ambiciozni planovi za premještanje i isključenje stanovništva, sve žigovi kasnijih akcija nacista na istom prostoru, karakterizirali su te operacije". 99

No za analiziranje pitanja je li rat mogao završiti već 1915. ključna je ova Watsonova teza: događanja na Istočnom bojištu 1915. imala su potpuno suprotni učinak na Centralne sile. Za Njemačko Carstvo, ruska invazija i okupacija Istočne Pruske ujesen 1914. i početkom 1915. imala je zapravo (iz ruske perspektive) kontraproduktivan učinak: odobravanje rata s Rusijom njemačke javnosti uz najviši stupanj potpore političkom i vojnom vodstvu. Osjećaj solidarnosti među njemačkim stanovništvom, koje je tražilo osvetu za zločine počinjene protiv njihovih sunarodnjaka, zapravo je poslužio tom istom vodstvu da rat predstavi kao obrambeni, u beskompromisnoj borbi "na život ili smrt" radi opstanka protiv agresora. Iako Watson kaže da su negativni demografski i socijalni učinci bili veliki: "Nekih 200 tisuća ljudi iz ugroženih područja otpraćeno je na sigurno početkom studenoga [1914., op. a.], a većina se raštrkala po sjevernoj i središnjoj Njemačkoj. Oko 50 tisuća ljudi u vlastitom je aranžmanu pobjeglo u unutrašnjost, a 100 tisuća prognanika putovalo je do zapadnih okruga Istočne Pruske"100, politički, vojni i ekonomski bili su maleni: "Invazija i nasilje koje je uslijedilo izazvali su velike patnje stanovništva Istočne Pruske, ali, poprilično nepromišljeno osnažili su širi njemački ratni napor. Reich je izgubio malo od ekonomske vrijednosti, jer je provincija prema nacionalnom standardu bila siromašna, poljoprivredna i rijetko naseljena. Samo je njezin glavni grad, Königsberg, bio važan, a on, srećom, nikada nije bio osvojen." ${ }^{101}$

Ni Stevenson se u svojem sveobuhvatnom djelu nije pozabavio tim pitanjem. Najoriginalniji zaključak u tom pogledu donosi Lieven. On smatra da je Rusija, bez obzira na katastrofu koju je doživjela 1915., zapravo imala veliku mogućnost pobijediti u ratu. Zbog zemljopisnih i komunikacijsko-prometnih značajki Istočnoga bojišta (velika prostranstva i udaljenosti, nedostaci željezničke mreže i loše ceste), Njemačka i Austro-Ugarska nisu mogle pobijediti. Njihov bi napor u postizanju toga cilja doveo do "točke pucanja" njihove industrije i oružanih snaga, uz veliki rizik zapostavljanja ostalih bojišnica, na kojima su bile suočene s još opasnijim neprijateljima od carske Rusije. Zato autor kaže: "Ruski generali i njihovo osoblje učili su iz iskustava i bez revolucije ruska bi vojska dala velik doprinos savezničkoj stvari 1917. godine. S ratnom proizvodnjom koja bi vjerojatno pala nakon 1917. ruske bi snage dale manji doprinos 1918., iako je to isto točno za Italiju i Austriju... U ruskom je slučaju pozadina, a ne bojišnica, prva kolabirala i potkopala ratni napor." ${ }^{102}$ S obzirom na činjenicu da se ruska vojska "organizirano povukla", pa čak i pobijedila

\footnotetext{
99 Isto, 205.

${ }^{100}$ Isto, 178.

${ }^{101}$ Isto, 179.

102 LIEVEN, Towards the Flame, 344.
} 
austrougarsku vojsku u Volinju u rujnu 1915., njegova je teza o "nedostatku ruskoga političkoga konsenzusa” kao uzročnika revolucije i ratnoga poraza iz ovoga kuta gledanja točna. ${ }^{103}$

Što se više proučava recentna literatura istaknutih povjesničara koji su se specijalizirali za Prvi svjetski rat, a bez upadanja u zamku revizionizma, moguće je da i prosječni čitatelj, a kamoli ne povjesničar, postavi pitanje: "Je li Prvi svjetski rat mogao završiti već 1915. kao posljedica događaja na Istočnom bojištu?" Tako sam i sam zaključio da je takav rasplet u vrlo visokom stupnju vjerojatnosti bio moguć. U tom pogledu složio bih se s Lievenom kada donosi zaključak ocjenjujući važnost borbi na Istočnom bojištu 1915. za prevlast u Srednoj i Istočnoj Europi. Smatra da je ishod tih borbi imao presudno značenje ne samo za neposredno zaraćene strane koje su se ondje sukobile nego i za cjelokupni ratni ishod, dakle za daljnju povijest cijeloga svijeta i formiranje novoga svjetskog poretka! "U ožujku 1918. Nijemci i Rusi potpisali su u Brest-Litovsku mirovni ugovor koji je okončao Prvi svjetski rat na Istočnom bojištu. U tom je ugovoru Rusija bila primorana priznati neovisnost Ukrajine kao neovisne države u načelu, a njemačkoga satelita u praksi. Da je ugovor iz Brest-Litovska ostao na snazi Njemačka bi dobila Prvi svjetski rat. Da dobije rat, Njemačka nije trebala izravnu pobjedu na Zapadnom bojištu." ${ }^{104}$

Može li se procijeniti broj poginulih, ranjenih, zarobljenih ili nestalih hrvatskih vojnika i časnika u borbama na Istočnom bojištu 1915 . godine?

Pregledom radova zaključuje se da je 1915. na Istočnom bojištu poginulo, ranjeno, nestalo ili zarobljeno najmanje 11 500, a najviše 24500 časnika i vojnika iz hrvatskih zemalja koji su se borili u sklopu austrougarskih vojnih postrojbi. Za potrebe ovoga rada nisu se koristile knjige iz serije Popis gubitaka u Prvom svjetskom ratu, sv. 1-42 (Beč, 1914.-1918.), koje se nalaze u Hrvatskom državnom arhivu u Zagrebu i u kojima su navedeni pojedinačni gubici austrougarske vojske za svaku godinu Prvoga svjetskog rata. ${ }^{105}$ Liste gubitaka

\footnotetext{
${ }^{103}$ No kada se usporede sljedeća dva navoda: “... Rusi su imali goleme gubitke. Do sredine 1915. godine izgubili su gotovo četiri milijuna ljudi”, u: DESPOT et al., Prvi svjetski rat, 11 i: "U sažetku koji je poslao caru, veliki vojvoda Nikolaj žalio se na jadnu kvalitetu zamjenskih novaka: 'Oni su ništa više nego jedva izvježbani seljaci, koji u nedostatku pušaka jedva da i znaju pucati”, u: BUTTAR, Germany Ascendant, 275, koji izvode suprotne zaključke, moglo bi se Lievenu prigovoriti za nedostatak te argumentacije zbog pomanjkanja prikaza konkretnih podataka u pogledu vojne snage i sastava ruske vojske za godine za koje sa sigurnošću tvrdi da bi ona mogla postići veliki uspjeh, pa i pobjedu u ratu.

${ }^{104}$ LIEVEN, Towards the Flame, 2.

${ }^{105}$ Pregledom knjiga Popis gubitaka u Prvom svjetskom ratu, sv. 7-24 (Beč, 1915.), koje se nalaze u Hrvatskom državnom arhivu u Zagrebu, za razdoblje od 3. siječnja do 30. prosinca 1915. došao sam do podatka o 1426000 poginulih pripadnika austrougarske vojske raznih nacionalnosti. Za neke je naznačeno mjesto pogibije (Rusija, Galicija itd.), a za druge nije, pa je teško iz te liste razaznati koliki se broj od ukupnoga broja odnosi na Istočno bojište, a koliki na druge bojišnice na kojima su hrvatski vojnici i časnici ratovali tijekom 1915. godine.
} 
iz Bečkoga ratnog arhiva djelomično su koristili Paščenko i Tominac u svojim radovima. Radi se o velikom broju žrtava, pogotovo ako se taj broj uzima u obzir kao udio u ukupnom broju stradalih (poginuli, ranjeni, zarobljeni, nestali) hrvatskih vojnika u Prvom svjetskom ratu tijekom svih godina rata i na svim bojišnicama. Do toga se broja došlo metodologijom analiziranja i usporedbe, prvenstveno općih podataka sadržanih u općoj hrvatskoj povijesti Dinka Šokčevića i radu skupine hrvatskih autora Prvi svjetski rat, a zatim podataka iz radova britanskih i hrvatskih autora.

Šokčević navodi: "Stanovništvo hrvatskih zemalja (uključujući Hrvate, Srbe i bosanske Muslimane) pretrpjelo je goleme žrtve u velikom ratu koji je uzrokovao slom Monarhije. Premda je pučanstvo Hrvatske i Slavonije, Dalmacije i Bosne i Hercegovine tvorilo tek 10\% ukupnog stanovništva Austro-Ugarske, u tim zemljama mobilizirano je 13-14\% pripadnika zajedničke vojske"106, a potom: "Hrvatske i bosanske postrojbe u bespoštednim borbama doživjele su teške gubitke. Na bojišnicama Prvog svjetskog rata poginulo je ukupno 190,000 vojnika mobiliziranih na području Hrvatske i Bosne i Hercegovine, uz više stotina tisuća ranjenih i jednako toliko zarobljenih na ruskoj i talijanskoj bojišnici." ${ }^{107}$ Vidljivo je dakle da je iznesen broj, ali je izostala detaljnija analiza prema pojedinim ratnim godinama, bitkama, lokalitetima itd. u vezi s brojem poginulih, zarobljenih, ranjenih i nestalih. U radu skupine hrvatskih autora Prvi svjetski rat stoji sljedeće: “... procjenjuje se da ih je iz hrvatskih krajeva poginulo između 60 i 100 tisuća." 108 Taj se broj odnosi na sve poginule hrvatske vojnike tijekom cijeloga razdoblja od 1914. do 1918. godine. U tom se kontekstu s pravom može zaključiti da je Istočno bojište 1915. za hrvatsku državu i hrvatski narod zapravo imalo u mnogim pogledima veću važnost od Talijanskoga, pogotovo kada se ima na umu da su podaci o uvjetima Londonskoga ugovora $^{109}$ hrvatskim političarima i javnosti postali poznati tek 1917. godine.

Freivogel donosi niz podataka koji uvelike odstupaju od onih iz radova britanskih i hrvatskih povjesničara, primjerice: "Austro-Ugarska je u godinu dana od 5,6 milijuna vojnika izgubila 56,989 časnika i dočasnika zajedno s

106 ŠOKČEVIĆ, Hrvatska od stoljeća 7. do danas, citirano iz: Ivo Goldstein, Hrvatska 1918. 2008. (Zagreb: EPH; Liber, 2008), 8.

107 ŠOKČEVIĆ, Hrvatska od stoljeća 7. do danas, 347.

${ }^{108}$ DESPOT et al., Prvi svjetski rat, 35.

${ }^{109}$ Londonski ugovor je tajni ugovor od 26. travnja 1915. Velike Britanije, Francuske i Rusije s Italijom, kojim su članice Antante obećale Italiji velike dijelove austrougarskoga teritorija kao nagradu za ulazak u rat na njihovoj strani i napuštanje dotadašnjih saveznika, Centralnih sila. Bassett iznosi ključni razlog talijanskoga ulaska u rat kada otvoreno piše da je konzorcij Rothschild podmitio talijanskoga kralja i vodeće političare da se pridruže Antanti: "U Londonu se Alfred de Rothschild ponudio da djeluje kao posrednik između talijanskoga veleposlanika Imperialija i britanskoga premijera Asquitha. Rothschild je bio jedan od mnogih koji su vrlo aktivno podupirali saveznike... Imperiali je poslije pisao talijanskom ministru vanjskih poslova San Giulianu da 'ga je netko tko radi u Cityju [financijsko središte Londona, op. a.] posjetio i ponudio mu 20.000.000 funti' Taj zapanjujući iznos, koji danas uvelike premašuje milijardu funti, bila je cijena koju je London stavio na prisiljavanje Austrije da otvori novu bojišnicu." BASSETT, For God and Kaiser, 486. 
2,484,548 poginulih, zarobljenih. U prosjeku je poginuo svaki osmi časnik i svaki deseti vojnik. 730 tisuća časnika i vojnika je zarobljeno ili nestalo, a 928 tisuća je teže ili lakše ranjeno. Unatoč stvaranju zamjenskih i novih postrojbi, broj ljudi na bojišnicama je bio manji nego početkom rata. Tako su 15. kolovoza 1915. c. i k. oružane snage na svim bojišnicama raspolagale s 29,113 časnika, 758,388 vojnika i 48,594 konjanika, ako se ne računaju male postrojbe na zapadnoj bojišnici i na Bliskom istoku." ${ }^{110} \mathrm{Na}$ temelju tih navoda doista je teško ustanoviti ili procijeniti broj stradalih hrvatskih vojnika, pogotovo zato što je u njegovoj knjizi izostala detaljna i specijalizirana analiza poput Buttarove.

Prema sveukupnom zbroju podataka iz Buttarove knjige, prateći kretanje jedinica sastavljenih od hrvatskih vojnika kojima su, prema autorima, zapovijedali hrvatski časnici (Borojević, Čičerić, Ljubičić i Puhallo), broj stradalih hrvatskih vojnika za cijelu 1915. iznosi visokih 24 500. Opet, nije ustanovljeno koliko od toga broja otpada na koju kategoriju. Precizan podatak iznosi Tominac u samo jednom dijelu, jer se njegov rad tematski odnosi na razdoblje od početka godine do kraja travnja 1915., kada su ratne operacije u Karpatima završile. Prema njegovu istraživanju: "Raspoloživa dokumentacija za izračune nije u cijelosti sačuvana, ali se može procijeniti da je poginulih i nestalih bilo preko 2.000. S ranjenima i zarobljenima sigurno se ukupni gubitci kreću preko 5.000 pripadnika." ${ }^{111}$

Buttar iznosi sljedeće podatke: "Carska i kraljevska vojska izgubila je približno 1,8 milijuna vojnika na ruskom bojištu 1915.; od toga ih je gotovo 800 tisuća bilo izgubljeno u pokolju na Karpatima. Raščlamba tih gubitaka tipična je za ono doba: otprilike 146 tisuća mrtvih, 510 tisuća ranjenih, 247 tisuća oboljelih i 328 tisuća zarobljenih... Njemački gubici na svim bojištima prešli su 600 tisuća, a na Istočno bojište otpada nešto više od trećine. Ruske su žrtve bile strašne. Približno milijun ljudi odvedeno je u zarobljeništvo i otprilike 500 tisuća ubijeno i isto toliko ranjeno. Čak ni veliki resursi Rusije nisu si mogli priuštiti takve gubitke; u najmanju ruku, Centralne sile mogle su se radovati produženom razdoblju smanjene aktivnosti svojih protivnika na istoku."112

Paščenko se u svojem radu u cijelosti koristio istraživanjem pukovnika Tominca te se tematski nadovezuje na njegov rad ondje gdje Tominac završava: "Vojnici iz Hrvatske sudjelovali su u bitkama na rijeci Dnjestar (9. do 12. svibnja 1915), u istočnoj Galiciji (srpanj-rujan 1915) i na rijeci Sereth (izvire u Ljvivs'koj oblasti, ulijeva se u Dnjestar. Bitka se vodila od 9. do 12. rujna). Hrvatske postrojbe sudjelovale su također u bitci kraj mjesta Sokalj (danas Ljvivs'ka oblast, sjeverno od grada Stryja), gdje su velike gubitke imale osobito između 13. i 16. lipnja. U izvješću od 17. lipnja 1915. zapovjedništvo navodi da je tih dana nestalo 54 časnika i 1,769 vojnika, ranjen je 1 časnik i 68 vojnika, a poginuo je 1 časnik i 15 vojnika. Posebno teške borbe vodile su se 15. lipnja 1915. kraj mjesta Kryvulja i Žydačov (okrug Lavova) - 31 poginulih,

\footnotetext{
${ }^{110}$ FREIVOGEL, Austrougarska vojska, 207.

111 TOMINAC, "Ličani u 'Velikom ratu”, 518.

112 BUTTAR, Germany Ascendant, 360.
} 
71 ranjenih i 1,319 nestalih. Izvješće od 17. lipnja, upućeno zapovjedništvu Grupe Szurmay, navodi da su se hrvatske postrojbe nakon teških bitaka svele na 481 vojnika. Nakon osvajanja Lavova te u prodoru prema istoku došle su na rijeku Bug, gdje su u teškim borbama ponovno pretrpjele goleme gubitke. U sukobima s Brusilovljevom vojskom sudjelovale su hrvatske postrojbe u pokrajini Volynj (15-18. rujna 1915), u Drugoj ofenzivi (23-30. rujna 1915) i u bitci za grad Rivne od 27. kolovoza do 8. listopada uz velike gubitke: 1,890 vojnika. Do kraja godine zadržali su se sjeverozapadno od grada Dubno, kraj sela Torgovyci u Volynju. Grupa Szurmay prošla je južno od grada Volodymyr Volyns'kyj i vodila borbe za strateški grad Luck, gdje je ušla u sastav 1. vojske generala Pavla Puhala, podrijetlom iz Like." 113

Uz navedeno, dao je precizan pregled mjesta kretanja hrvatskih postrojbi u Bukovini tijekom 1915. (Černjivci, Okna, Buč), ali u vezi s tim borbama ne donosi podatak o ukupnom broju stradalih (poginulih, ranjenih, zarobljenih ili nestalih) ${ }^{114}$ kako to čini za galicijski dio bojišnice, navodeći kao razlog da su ti vojnici "dospijevali u zarobljeništvo, a najčešće su ih odvodili u zarobljeničke logore na dalekom istoku, odakle su se nakon završetka rata vraćali uz velike poteškoće. Velik broj zauvijek je ostao na dalekim azijskim prostranstvima, gdje su pokopani najčešće u neobilježenim grobnicama"."115

U procjeni broja sveukupno stradalih donosi nešto uvećani broj: “Najviše ih je poginulo na bojištima u Galiciji, Volynju i Bukovini: od 1914. do kraja rata između 100,000 i 150,000 vojnika." ${ }^{116}$ Za 1915., uzimajući u obzir sve podatke koje je iznio u svojem radu, dolazi se do broja od 5261 stradalih za koje se prema metodologiji koju je koristio Paščenko sa sigurnošću može reći da su bili hrvatski vojnici u sklopu austrougarskih postrojbi na Istočnom bojištu 1915. godine. No taj broj ni približno nije potpun jer ne obuhvaća mnoge postrojbe za koje autor kaže da su sudjelovale u borbama, ali nema dovoljno podataka da bi ustanovio što se tim ljudima dogodilo.

Paščenko je nabrajanjem brojnih lokaliteta vojnih i drugih groblja u današnjoj zapadnoj Ukrajini i južnoj Poljskoj pokušao ustanoviti što se dogodilo sa svim tim ljudima koji su poginuli na tim dijelovima bojišta. U istraživanju je nailazio na brojne probleme, pa tako kaže da postoji mnogo zajedničkih grobnica u kojima je jako teško ili gotovo nemoguće ustanoviti identitet po nacionalnoj pripadnosti pojedinoga vojnika, mnogo neobilježenih grobnica te pojedinačnih grobova prema čijim lokalitetima postoje naznake da su hrvatske postrojbe sudjelovale u borbama na njihovu užem ili širem području, ali je potpuno neprikladno u nedostatku neke snažne poveznice tvrditi da su upravo to grobovi hrvatskih vojnika.

\footnotetext{
${ }^{113}$ PAŠČENKO, Hrvatski grobovi 1914. - 1918., 44.

${ }^{114}$ Isto, 48.

${ }^{115}$ Isto, 49.

116 Isto, 37.
} 
Zanimljiva su dva navoda. Prvi glasi: "Osim poginulih u ratnim sukobima, umirali su i ranjenici i bolesnici. U karpatskim bitkama 1915. ranjenike i oboljele od smrzavanja najčešće se prevozilo u bolnice središnjeg grada Zakarpatja - Užgoroda. Ondje su bili i ljudi s hrvatskih prostora, gdje su mnogi završili na bolničkim grobljima... Suvremeni ukrajinski izvori priopćuju da arhivski podaci o pokopanima (ime, prezime i mjesto podrijetla) spominju i 110 imena s hrvatskih prostora, a čuvaju se u Pragu." ${ }^{117}$

U drugom ostavlja mogućnost da su hrvatski vojnici pokopani na pojedinim lokalitetima, ali pod drugim imenom: "U okolici mjesta Galyč, smještenog $29 \mathrm{~km}$ istočno od Ivano-Frankivs'ka, poginulo je mnogo vojnika s obje strane. Prema ukrajinskim izvorima, bilo je više od 500 pokopa, a danas je očuvano 314 grobova, u zapuštenom stanju. Obnovu je vodila mađarska strana, obilježivši neka imena ugarskoga podrijetla, ali ne i hrvatska." ${ }^{118}$

U konačnici, čitajući Paščenkovu knjigu o do sada potpuno nepoznatim sudbinama hrvatskih, ali i drugih vojnika, nailazi se na mnoge vrijedne izvore za proučavanje hrvatske povijesti. Neki su se hrvatski povjesničari počeli intenzivnije baviti temom hrvatskih vojnika i časnika stradalih u "bijelom paklu" Karpata i na nepreglednim ukrajinskim i ruskim ravnicama tijekom cijeloga razdoblja žestokih borbi na Istočnom bojištu od ljeta 1914. do zime 1917., a pokrenuta je i inicijativa redovitoga obilježavanja tih tragičnih događaja: pukovnik Tominac s izaslanstvom Grada Zagreba ove je godine prisustvovao takvu događaju u selu Dobrinivci u Bukovini (današnja zapadna Ukrajina). ${ }^{119}$

Ukratko, Paščenko kaže da ne postoje materijalni dokazi da se radi o hrvatskim postrojbama. No ono što je sigurno, dokazano i ustanovljeno tom zapravo arheološko-antropološkom metodologijom rekonstrukcije brojnih sudbina hrvatskih vojnika lokaliteti su obilježenih skupnih i pojedinačnih grobnica hrvatskih vojnika koje je autor poimenično navodio, pa je barem u tom dijelu učinjen važan pomak u hrvatskoj historiografiji Prvoga svjetskog rata. Dakle, prema podacima Paščenka i Tominca, poznatih je žrtava preko 10 tisuća, a nepoznatih, prema njihovim zaključcima, sigurno još toliko. S tim u vezi Herman Kaurić kaže: "Ostaje nepoznato koliko je ljudi s teritorija Hrvatske i Slavonije unutar austrougarskih 519365 mrtvih ili koliki je broj tih ljudi unutar 8,2 milijuna vojnika mobiliziranih u austrougarske borbene snage. Vjeruje se da je devet od sto ljudi bilo mobilizirano, što bi, prema službenom popisu iz 1910., značilo da je najmanje 756 tisuća ljudi iz Hrvatske i Slavonije služilo u vojsci tijekom rata. Usto, vjeruje se da je 20 od 1000 ljudi umrlo ili bilo ubijeno, što bi dovelo do procjene o 100 tisuća poginulih vojnika i otprilike toliko civila koji su umrli tijekom rata, najviše od raznih bolesti." ${ }^{120}$

\footnotetext{
${ }^{117}$ Isto, 56.

${ }^{118}$ Isto, 66.

${ }^{119} \mathrm{Na}$ toj lokaciji nalazi se spomen-obilježje 25. domobranske pješačke pukovnije s natpisom “BOG I HRVATI. KR. UC. ZAGREB. 25. DOM PJ.P. SLAVA IM 1915-16”.

${ }^{120}$ HERMAN KAURIĆ, “The First World War in Croatia”, 20.
} 
Watson je u svojoj knjizi na nekoliko mjesta navodio broj stradalih. I kod njega je primjetno da kategorije (poginuli, ranjeni, zarobljeni, nestali) nisu posebno istaknute, pa se broj poginulih Hrvata na Istočnom bojištu 1915. teško može ustanoviti. Eventualni okvir za to daje „tablica 5 Etnički sastav austrougarske vojske 1915. (prema jeziku)“. ${ }^{121}$ Prema podacima u tablici, Hrvati su činili $2,7 \%$ aktivnih časnika, 1,9\% pričuvnih časnika i 9,2 \% vojnika. Kada se to usporedi s Tominčevim podacima: "U drugoj polovici siječnja 1915. godine u zoni odgovornosti snaga Centralnih sila na Istočnom bojištu naći će se ukupno 553.244 pušaka, 3.015 artiljerijskih oruđa i 37.246 konja" ${ }^{122}$, proizlazi da se u tom trenutku na Istočnom bojištu nalazilo 65836 hrvatskih vojnika i časnika.

$\mathrm{S}$ druge strane, kada se uzmu u obzir i stave u kontekst podaci iz knjige Prvi svjetski rat. Čitanka-priručnik, prema kojima je do kraja rata poginulo 1 773700 njemačkih vojnika, 1,2 milijuna austrougarskih državljana i 1,7 milijuna ruskih vojnika, ${ }^{123}$ opet se može samo s većom sigurnošću ustanoviti ukupan broj poginulih vojnika u cijelom ratu, koji u tom slučaju iznosi 142800 , a točan broj ukupno stradalih na Istočnom bojištu 1915. ostaje neutvrđen. S obzirom na metodologiju koju je Watson iznio u svojoj knjizi, osobno sam stava da je broj stradalih hrvatskih časnika i vojnika na Istočnom bojištu 1915. znatno veći od do sada navedenog u službenim publikacijama (liste gubitaka austrougarske vojske) i historiografiji. Još uvijek postoje mnoge lokacije neutvrđenih grobnica i grobova (od kojih je neke spomenuo Paščenko) među kojima je teško razlučiti gdje su hrvatski vojnici. Sve u svemu, Buttarov podatak da je iz stroja izbačeno 1,8 milijuna časnika i vojnika austrougarske vojske na Istočnom bojištu 1915. držim preciznijim i realnijim od ostalih do sada iznesenih podataka. Ako se podaci i metodologija u Watsonovu istraživanju etničke strukture austrougarske vojske u izračunu udjela poginulih Hrvata u sveukupnom broju poginulih pripadnika austrougarske vojske primijene na taj navod, proizlazi da je bilo 18432 poginula, 36920 ranjenih, 22724 oboljela i 30176 zarobljenih hrvatskih vojnika. Dakle, sveukupno 108252 vojnika iz hrvatskih zemalja izbačeno iz stroja samo na Istočnom bojištu 1915. godine! Koliki god bio stvaran broj stradalih, a držim da je ovom metodologijom postavljen solidan okvir za određivanje toga broja, taj je udio u ukupnom broju poginulih hrvatskih državljana tijekom cijeloga rata znatan. Zato i smatram da je proučavanje događaja na Istočnom bojištu 1915. važno za cjelokupnu hrvatsku historiografiju o Prvom svjetskom ratu.

\section{Zaključak}

Iz ovoga pregleda radova vidljivo je da su događanja na Istočnom bojištu 1915. izazvala dovoljno veliko zanimanje pojedinih britanskih i hrvatskih

\footnotetext{
${ }^{121}$ WATSON, Ring of Steel, 286.

${ }^{122}$ TOMINAC, "Ličani u 'Velikom ratu", 498.

${ }^{123}$ DESPOT et al., Prvi svjetski rat, 11.
} 
povjesničara da bi ih potaknula na pisanje novih radova o Prvom svjetskom ratu. U kratkom razdoblju od 2014. do danas u britanskoj i hrvatskoj historiografiji napravljen je važan pomak prema većem broju specijaliziranih radova koji se bave političkom, vojnom i društvenom poviješću u proučavanju Istočnoga bojišta u Prvom svjetskom ratu. Ti su radovi važni za daljnje proučavanje hrvatske povijesti iz nekoliko razloga: prvo, donose obilje novih podataka i objavu novih izvora. U pojedinim tematskim dijelovima neki autori multidisciplinarnim pristupom kontekstuiraju te događaje prikazujući ih u novom svjetlu. Takva se istraživanja mogu iskoristiti za popunjavanje "historiografskih praznina" koje, kako se vidi iz prikaza, postoje unutar ovoga predmeta istraživanja teme o Prvom svjetskom ratu u obje historiografije.

Tako se može slijediti metodologija za određivanje preciznijega broja stradalih (poginulih, ranjenih, zarobljenih i nestalih) hrvatskih vojnika na Istočnom bojištu, jer u pogledu toga još uvijek ne postoji konsenzus hrvatskih povjesničara koji se bave ovom temom. Drugo, od koristi su i nepovjesničarima, u pronalaženju predaka koji su kao sudionici tih događaja bili osuđeni na tragičnu sudbinu, a nemali broj njih nikada nije ni pronađen (što je vidljivo u primjeru radova Paščenka i Tominca). Treće, budući da su pojedini radovi britanskih i hrvatskih autora doživjeli veliki komercijalni uspjeh, od koristi su budućim povjesničarima koji nisu primarno zainteresirani za teme iz Prvoga svjetskog rata da se specijaliziraju za to područje kako bi se historiografski okvir upotpunio novim radovima.

Svi ti radovi napisani su zanimljivo, u smislu da su autori uspjeli prijeći okvir suhoparnoga kronološkog navođenja bitnih (a zapravo dosadašnjoj bibliografiji općepoznatih) događaja i u velikoj mjeri skrenuti pozornost na događaje koji nisu bili toliko obrađivani u dosadašnjim radovima britanske i hrvatske historiografije. Zaključak je većine britanskih autora gotovo identičan: konačan ishod vojnih operacija 1915. na Istočnom bojištu "zapečatio je sudbinu zaraćenih carstava", ali s potpuno suprotnim učinkom. Hrvatski se autori nisu toliko bavili pitanjem ishoda ratnoga sukoba koliko pitanjem otkrivanja sudbine poginulih, ranjenih, nestalih i zarobljenih hrvatskih vojnika kao i onih kojima se nepovratno izgubio trag. Time su postavili dobar okvir za proučavanje "kulture sjećanja" i svakako bitno pridonijeli stvaranju kolektivne memorije javnosti i povjesničara o tim događajima svjetskoga značaja. U tim radovima postoji dovoljno primarnih i sekundarnih izvora za cjelovitu knjigu iz vojne povijesti o hrvatskim postrojbama koje su se borile i ginule na Istočnom bojištu u Prvom svjetskom ratu.

Proučavanjem tih radova može se zaključiti da su hrvatski vojnici ipak imali itekako dobar razlog i jasan cilj da idu u rat: boriti se za svoju domovinu. To je ujedno glavna teza i svrha ovoga rada: istaknuti važnost događaja na Istočnom bojištu i upozoriti na činjenicu da je to bojište imalo mnogo veću važnost nego što mu se pridaje (ili se pridavala) u dosadašnjoj hrvatskoj historiografiji. U konačnici, koristeći se istraživanjima britanskih i hrvatskih autora 
za uklapanje u cjelokupni povijesni narativ o Prvom svjetskom ratu, mogao bi se postići znatan doprinos kvaliteti obiju historiografija.

\section{Literatura}

BASSETT, Richard. For God and Kaiser. The Imperial Austrian Army. New Haven; London: Yale University Press, 2016.

BUTTAR, Prit. Germany Ascendant. The Eastern Front 1915. London: Osprey Publishing, 2015.

DESPOT, Igor; HAMERŠAK, Filip; HERMAN KAURIĆ, Vijoleta; MILJEVIĆ PAVIĆ, Helena; ŠKULJEVIĆ, Krešimir. Prvi svjetski rat. Čitanka-priručnik za učitelje i profesore povijesti u osnovnoj školi i gimnaziji. Zagreb: Školska knjiga, 2014.

FREIVOGEL, Zvonimir. Austrougarska vojska u prvom svjetskom ratu. Zagreb: Despot infinitus, 2014.

HERMAN KAURIĆ, Vijoleta. "The First World War in Croatia - More or less known facts". Review of Croatian History 10 (2014), br. 1: 6-16.

LIEVEN, Dominic. Towards the Flame. Empire, War and the End of Tsarist Russia. London: Penguin, 2016.

PAŠČENKO, Jevgenij. Hrvatski grobovi 1914. - 1918. Karpati, Galicija, Bukovina. Zagreb: Hrvatski državni arhiv, 2016.

STEVENSON, David. 1914. - 1918. Povijest Prvog svjetskog rata. Preveo Vuk Perišić. Zagreb: Fraktura, 2014.

ŠOKČEVIĆ, Dinko. Hrvatska od stoljeća 7. do danas. Zagreb: Durieux, 2016.

TOMINAC, Nikola. "Ličani u 'Velikom ratu'. Zimska bitka za Karpate, siječanj-travanj 1915”. Senjski zbornik : prilozi za geografiju, etnologiju, gospodarstvo, povijest i kulturu 42-43 (2016), br. 1: 489-524.

WATSON, Alexander. Ring of Steel. Germany and Austria-Hungary at War, 1914-1918. London: Penguin Books, 2015. 


\section{SUMMARY}

\section{The Eastern Front in 1915 in the Newest British and Croatian Historiography}

This paper analyses the latest works of certain British and Croatian authors on the events set into motion by the military operations and battles that took place on the Eastern Front in 1915, during World War I. Their points of views and conclusions on the topic have been represented by placing the works into two separate groups, characterised by the criterion of the author's approach to the subject at hand. Some of these works proved to be an incentive for some Croatian historians to focus their research on this field, taking a more specialized approach to the topic of the Eastern Front in 1915. For that reason, a comparative scientific method has been used in this paper in order to emphasize the similarities and differences within certain aspects of the analyses conducted by these authors. By stressing the importance of incorporating these British and Croatian authors' extensive research into official World War I historical narratives, it is essential to draw the conclusion that a significant contribution to the overall quality of historiography might be achieved by using this particular approach.

Key words: Eastern Front; World War I; British historiography; Croatian historiography; Austro-Hungarian army; German army; Russian army. 